\title{
A Látrányi Puszta Természetvédelmi Terület fullánkos hártyásszárnyú (Hymenoptera, Aculeata) faunája
}

\author{
JóZAN ZsoLT
}

\author{
H-7453 Mernye, Rákóczi út 5., Hungary
}

Józan Zs.: Aculeata fauna of the Látrányi Puszta Nature Conservation Area (Hymenoptera: Aculeata) Abstract: In the following report, the author summarises the results of the faunistical investigation carried out in the vicinity of the Látrányi Puszta Nature Conservation Area (Hungary, Southern Transdanubia) over several decades. The number of the species collected is significant: 14 Scolioidea, 30 Chrysidoidea, 34 Pompiloidea, 19 Vespoidea, 104 Sphecoidea and 202 Apoidea species. The fauna is evaluated according to its zoogeographycal and eco-faunistical values. A table is provided for the species occurring in the different types of habitats. From faunistical point of view, the most significant species are: Parnopes grandior, Chrysis angustifrons, (Chrysidoidea), Belomicrus antennalis, Cerceris somotorensis, (Sphecoidea), Andrena chrysopus, Nomada calimorpha, Bombus argillaceus (Apoidea).

Key words: Aculeata, faunistical survey, Hungary

\section{Bevezetés}

A Somogytúr és Látrány határában fekvő pleisztocén eredetű homokterület fullánkos faunáját a szerző az 1970-es évek közepétől kisebb-nagyobb megszakításokkal folyamatosan vizsgálta. Általában évente egy-két alkalommal végzett terepmunkát a Nyíres-legelő és a Birkás-legelö határrészeken, föleg a nyári aszpektus fajait gyüjtve. Már ebben az időszakban előkerültek azok a ritka homokkedvelő fajok, amelyek a később létesített természetvédelmi terület faunisztikai értékeit adják. A rendszeres feltáró munkát 1999ben és 2001-ben folytatta. Ekkor már a védett terület határain belül, annak egyes részeit külön vizsgálva történt a terepmunka. Az egyes élőhely típusok faunulái, viráglátogatási szokások is vizsgálatra kerültek.

\section{Anyag és módszer}

A felvételek egyeléssel, fühálózással és lombhálózással történtek. Már márciusban, a rekettyefüz virágzásának idején elkezdődtek a gyüjtések, nyár végéig folyamatosan kéthárom hetente ismétlödtek. A felvételezések a száraz- és a nedves gyepekre, a magaskórósokra, cserjésekre, erdei aljnövényzetre, gyepüszegélyekre egyaránt kiterjedtek. Összesen: 403 faj került elő, mintegy 1400 példányban.

\section{A gyüjtöhelyek jellemzése}

A védett terület hét kisebb területén folytattuk a gyüjtéseket, ahol a környezeti tényezők lehetővé tették a gazdagabb fullánkos faunulák kialakulását. Mindegyikre jellemző, hogy itt a növényzet változatos, mozaikkomplex térszerkezetü, illetve dominál a szegélyhatás (1. ábra). 
1. A Kolláti-legelő középső sávjának déli része. Itt a zárt és nyílt homokgyepekben történt a gyüjtés. A területen észak-déli irányban húzódó földút környékén a csapadékos időszakban időszakos tó keletkezik. Környékén szabad homokfelület, nyílt és zárt homokgyep váltakozik.

A sajátos fajegyüttes a táplálékforrás (pollen, nektár, zsákmányállat) - fészkelöhely gazdaállat összefüggésrendszerében alakult ki.

2. A Kolláti-legelő nyugati határterülete. Itt a Látrány község belterületével határos területen a gyomosodás következtében jelentős a pollen és nektárkínálat. A közeli épületek a xylicol fajok és az ún. "fali ökoszisztémák" tagjainak megjelenést biztosítják.

3. A Látrány-Andocs müút kanyarulatától délnyugatra fekvő gödrökkel, homoksáncokkal tagolt terület. A nyílt homokfelületeik, nyílt gyepfragmentumok, a fásszárúak (füz, nyár, stb.) jelenléte kedvez a fullánkos fauna diverzitásának. A közeli bokorfüzes a korai rajzású méhfajok számára nyújt táplálékforrást.

4. A Tukora tanya környéke. Ez a gyüjtőhely az eltérő jellegü élöhelyek mozaikkomplexe. Kis távolságon belül száraz homokgyep, sásos-gyékényes, magaskórós, láprét, füzliget, nyárfák, akácgyepü található. Az innen előkerült fajegyüttes is változatos, a nedvességkedvelő fajok dominálnak.

$5 \mathrm{a}$ - 5b. A Látrány-Andocs müút keleti oldala mentén. Itt a nyilt és zárt homokgyepekben több melegkedvelő faj került elö. A legjelentősebb ezek közül a Dioxys tridentata. A Eryngium campestre virágait sajátos fajegyüttes látogatja, ezek közül megemlítjük a Scolia és Campsocolia fajokat, valamint a Larrinae és Sphecinae alcsaládba tartozó kaparódarázs fajokat. Az Euphorbia fajok itt is jelentős tápanyagforrásul szolgálnak.

6. A Látrány-Andocs müúttól nyugatra az elektromos távvezeték környékén. Többféle élőhely találkozása mentén a fajdiverzitás jelentősebb, mint a homogén társulású területeken. A müút melletti szántóföld gyomflórája a méhszerü fajok számára igen jelentős, különösen az Andrena fajok látogatják a Raphanus raphanistrum és a Sinapis arvensis virágait.

7. A 67-es müúttól keletre a Nyíres-legelő határrészen. Ezen a területen a nyílt és zárt homokgyepekben történtek a gyüjtések a telepített erdei fenyves közelében. Itt találtuk meg a védett Parnopes grandiort és gazdaállatát, a Bembix rostratat. Megfigyelhettük, amint e kaparódarázs nőstényei egy-egy vakondtúrást elfoglalva, néhány deciméter távolságban 5-6 fészket mélyítettek.

\section{Eredmények}

\section{Faunisztikai és ökofaunisztikai értékelés}

Az elökerült 403 faj az alig három négyzetkilométernyi területhez viszonyítva igen jelentősnek mondható. A szerző által vizsgált más területekkel összehasonlítva még inkább megmutatkozik e fajszám magas volta. A jóval nagyobb területü Boronka-melléki TK-ben és a Zselicben ugyan több fajt sikerült gyüjteni, de a területi arányokat és a környezeti változatosságot tekintve a különbség nem számottevő. A Tihanyi-félszigeten csak az Apoidea fajok száma különbözik jelentősen a Látrányi-Puszta TT-étől (3. táblázat).

A Sphecoidea fajok alcsaládonkénti megoszlása a homokvidékekre jellemzően alakult. A teljes hazai faunához képest a Sphecinae és Larrinae fajok száma magas, megközelíti a hazai összfajszám 50\%-át. A legalacsonyabb a Pemphredoninae fajok részaránya csak $25 \%$. A többi alcsaládban a fajok részaránya közepes, a teljes hazai fajszám $30-$ 39\%-a. Az Apoidea fajok alcsaládonkénti megoszlását vizsgálva a legmagasabbnak bizonyult a Colletidae, Andrenidae és a Halictidae fajok részesedése, a hazai összfajszám 35-39\%-a. Igen alacsony az Anthoporidae fajoké, mindössze 16\%,a többi családé 28- 


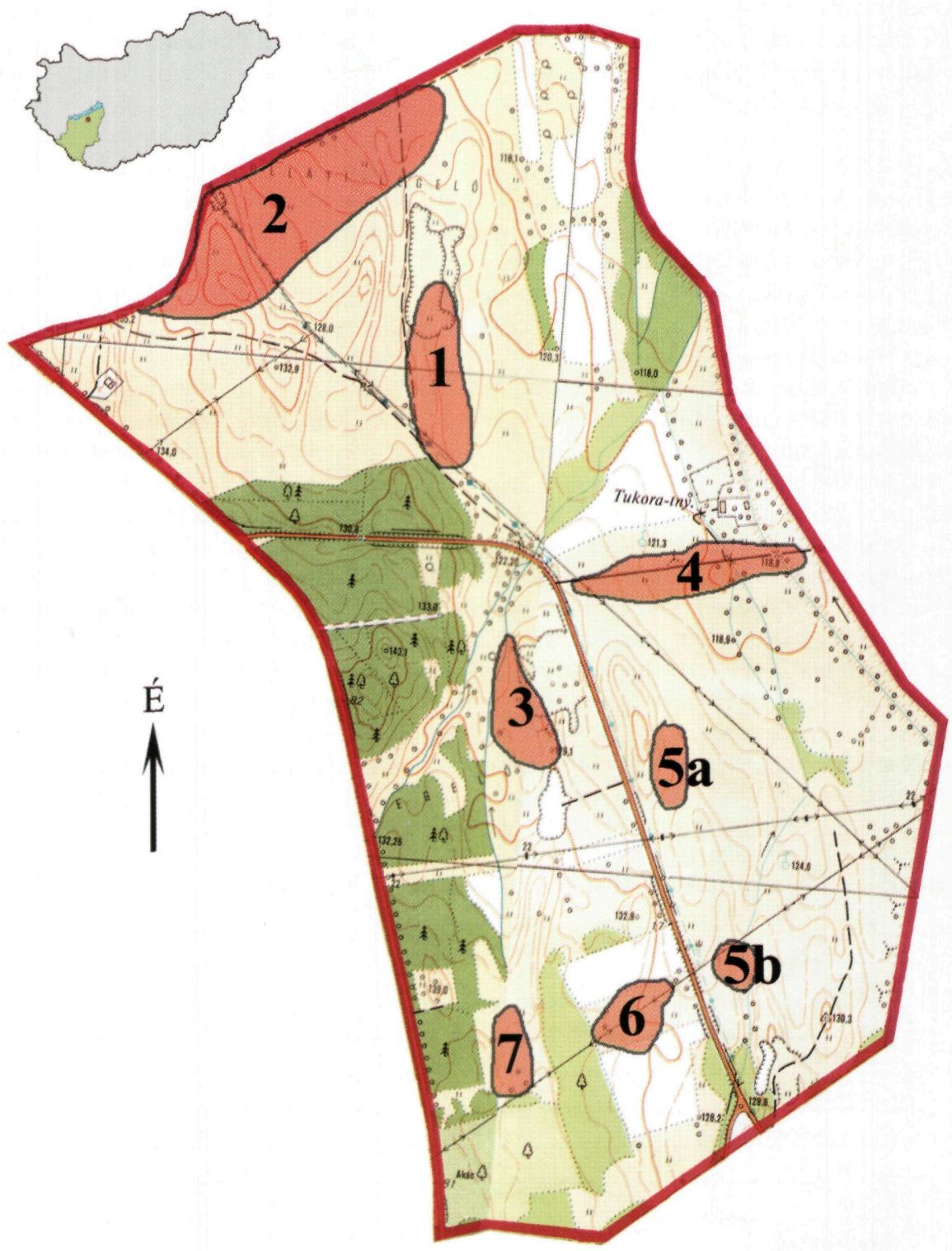


33\% között változik. A Látrányi Puszta TT. és más homokterületeken előkerült fajok megoszlását összehasonlítva azt állapíthatjuk meg, hogy itt a vizsgált területen legfajgazdagabb a Sphecinae és a Crabroninae alcsalád, illetve az Andrenidae család (4-5. táblázat).

Az előkerült fajok 47\%-a széles elterjedésű, az európai taxonok részesedése $28 \%$, míg a déli elterjedésủeké $28,5 \%$. A száraz gyepekben és a nedves élőhelyeken előkerült fajok csoportjai közt kialakult különbségek a széles elterjedésủeknél 8\%-ot, az európaiaknál 2\%-ot, míg a déli elterjedésủeknél 5\%-ot tesznek ki (1. táblázat).

Az eremophil fajok túlsúlya különösen a száraz gyepekben élö fajcsoportnál szembetűnő. A stenök faunaelemek aránya itt megközelíti a 15\%-ot, az euryök elemeké pedig az 52\%-ot. A nedves élőhelyeken előkerült hylophil faunaelemek $24 \%$-os részesedése más kutatott területekhez képest nem mondható magasnak (2. táblázat).

Négy élőhelycsoportban vizsgáltuk meg a fajok összetételét: száraz gyepek (nyílt- és zárt gyeptársulások), nedves rétek és magaskórósok (a sásos mocsaras szegélytársulásokkal együtt), erdei jellegű biotópok (erdőszegélyek, gyepük, füzesek, erdei gyepszintek), gyomtársulások. Az előkerült fajok a fajjegyzékben találhatók.

A védett terület legjellegzetesebb fullánkos fajai a száraz, buckahátakon kialakult gyeptársulásokba élnek, főleg a csupasz homokfelületeken, a körülöttük kialakult nyílt gyepek mozaikjaiban. Kevesebb faj került elő a zárt gyepekben, különösen ott, ahol kevés a kétszikủ növényfaj. A Scolioidea fajok közül innen csak a két Myrmosa faj nem került elő. Ezek a fajok ezen élőhelytípus legjellegzetesebbjei között tarthatók számon. A Chrysidoidea csoportban csak itt fordul elő az Elampus scutellaris, Holopyga fervida, két Hedychridium faj, a Parnopes grandior, a Spinolia unicolor, a Chrysis angustifrons, $C h$. pulchella, Ch. splendidula és a Ch. succincta. E fajok többsége ritka, vagy közepesen ritka színező faunaelem. Az Omalus violaceus és a Chrysis trimaculata egy-egy példánya is itt került elő, de biztosra vehető, hogy csak táplálkozni repültek ide. A Pompiloidea fajok közül a nyílt homokgyepek karakterisztikus fajai az Eoferreola manticata, a Pompilus cinereus, az Aporinellus sexmaculatus és az Evagetes fajok, valamint gazdaállatuk, az Episyron rufipes. A Vespoidea fajok közül erősen ragaszkodik a homoki élőhelyekhez a Pterocheilus phaleratus. A többi csak innen előkerült redősszárnyú-

\section{1. táblázat: A fajok megoszlása állatföldrajzi jellegük szerint (\%) (Scolioidea fajok nélkül)}

\begin{tabular}{|l|c|c|c|}
\hline elterjedési jelleg & száraz gyepek & $\begin{array}{c}\text { nedves rétek, } \\
\text { magaskórósok }\end{array}$ & összes faj \\
\hline holarktikus & 2.3 & 5.3 & 2.7 \\
\hline palearktikus & 33.0 & 36.2 & 34.2 \\
\hline nyugat-palearktikus & 6.4 & 4.0 & 3.5 \\
\hline euroszibériai & 3.4 & 7.3 & 6.5 \\
\hline európai & 16.2 & 16.6 & 15.1 \\
\hline közép-európai & 2.6 & 2.0 & 2.7 \\
\hline észak- és közép európai & 2.3 & 1.3 & 2.2 \\
\hline atlantikus & 1.9 & 0.7 & 1.9 \\
\hline holomediterrán & 12.8 & 7.3 & 11.6 \\
\hline pontomediterrán & 10.5 & 11.3 & 11.0 \\
\hline északmediterrán & 6.0 & 6.0 & 5.9 \\
\hline pontusi, pontokaszpikus, szarmata & 2.6 & 2.0 & 2.7 \\
\hline
\end{tabular}


2. táblázat: A fajok megoszlása ökofaunisztikai jellegük szerint (\%)

\begin{tabular}{|l|c|c|c|}
\hline ökofaunisztikai jelleg & száraz gyepek & $\begin{array}{c}\text { nedves rétek, } \\
\text { magaskórósok }\end{array}$ & összes faj \\
\hline stenoök eremophil & 9.4 & 2.7 & 7.2 \\
\hline euryök eremophil & 51.9 & 40.6 & 47.3 \\
\hline hipereuryök intermedier & 29.3 & 32.4 & 26.6 \\
\hline euryök hylophil & 9.4 & 24.3 & 18.9 \\
\hline eremophil/hylophil arány & 6.5 & 1.8 & 2.9 \\
\hline
\end{tabular}

3. táblázat: A gyửjtött fajok megoszlása családsorozatonként, összehasonlítva más területekkel

\begin{tabular}{|l|c|c|c|c|c|}
\hline családsorozat & $\begin{array}{c}\text { Látrányi- } \\
\text { puszta TT. }\end{array}$ & $\begin{array}{c}\text { Baláta TT. és } \\
\text { környéke }\end{array}$ & $\begin{array}{c}\text { Boronka- } \\
\text { melléki TK }\end{array}$ & Tihanyi TK & Zselici TK \\
\hline Scolioidea & 14 & 11 & 16 & 13 & 13 \\
\hline Chrysidoidea & 30 & 36 & 36 & 24 & 42 \\
\hline Pompiloidea & 34 & 25 & 50 & 25 & 42 \\
\hline Vespoidea & 19 & 26 & 35 & 29 & 40 \\
\hline Sphecoidea & 104 & 97 & 138 & 91 & 135 \\
\hline Apoidea & 202 & 181 & 259 & 334 & 389 \\
\hline Összesen & 403 & 383 & 534 & 516 & 661 \\
\hline
\end{tabular}

darázs faj más meleg és száraz élőhelyen is előfordul. Említést érdemel ezek közül a Parodontodynerus ephippius, a Polistes associus és a $P$. omissus. A Sphecinae fajok közül ehhez az élöhelytípushoz egyértelmüen kötődik a Sphex rufocinctus. Ez a védett fajok jegyzékében szereplö állat nem mondható olyan ritkának, hogy a védelme indokolt lenne. Továbbá homokkedvelők a Prionyx kirbyi, az Ammophila terminata mocsaryi és a két Podalonia faj. A Pemphredoninae alcsalád fajai közül egy a Mimesa faj került elö eddig csak homokterületeken. A többi ide tartozó faj nem ennek az élöhelytípusnak a lakója. A négy Astatinae faj közül (Astata, Dinetus) hármat csak itt gyüjtöttünk. A Larrinae alcsalád fajainak zöme preferálja a homoki élöhelyeket. Ez itt is megmutatkozott. A Tachytes, Tachysphex, Miscophus fajok túlnyomó többsége és a Palarus variegatus innen került elő. A Crabroninae fajok közül csak itt került elő a ritka Belomicrus italicus, az Oxybelus lineatus, a közepesen gyakori Oxybelus victor és a Lestica alata. A Nyssoninae alcsalád fajai közül ennek az élöhelynek jellegzetes tagjai a Dienoplus elegans, a Bembix fajok és a Bembecinus tridens. Ez utóbbi faj a nyílt homokfelületeken csoportosan fészkelve helyenként domináns fajként lép fel. A $N y s s o n$ fajok közül a $N$. dimidatus és a $N$. maculosus tartozik ide, bár a közeli cserjés és fás szegélytársulásokban is megjelennek.

A méhszerü fajok közül ennek az élöhelytípusnak jellegzetes tagjai: Hylaeus punctulatissimus, Colletes hylaeiformis, C. marginatus, C. pallescens, Andrena mocsaryi, A. numida hypopolia, $A$. potentillae, Halictus semitectus, Lasioglossum convexiusculum, $L$. quadrinotatulum, a Sphecodes fajok többsége, a Dasypoda hirtipes, Anthidium strigatum, Stelis signata, Dioxys tridentata, Metallinella brevicornis, Coelioxys afra, C. bre- 
4. táblázat: A Sphecoidea fajok megoszlása alcsaládonként, összehasonlítva más területekkel

\begin{tabular}{|l|c|c|c|c|c|c|}
\hline alcsaládok & $\begin{array}{c}\text { Látrányi- } \\
\text { puszta TT. }\end{array}$ & $\begin{array}{c}\text { Baláta-tó és } \\
\text { környéke }\end{array}$ & $\begin{array}{c}\text { Bugac- } \\
\text { puszta }\end{array}$ & $\begin{array}{c}\text { Bátorligeti } \\
\text { TT. }\end{array}$ & $\begin{array}{c}\text { Tihanyi } \\
\text { TK }\end{array}$ & $\begin{array}{c}\text { Zselici } \\
\text { TK. }\end{array}$ \\
\hline Ampulicinae & & 1 & 1 & & & 1 \\
\hline Sphecinae & 10 & 8 & 11 & 8 & 7 & 7 \\
\hline Pemphredoninae & 13 & 16 & 12 & 16 & 16 & 27 \\
\hline Astatinae & 4 & 3 & 8 & 2 & 2 & 4 \\
\hline Larrinae & 18 & 21 & 22 & 11 & 9 & 21 \\
\hline Crabroninae & 33 & 28 & 27 & 29 & 30 & 43 \\
\hline Nyssoninae & 18 & 14 & 20 & 16 & 15 & 22 \\
\hline Philanthinae & 8 & 6 & 10 & 9 & 12 & 10 \\
\hline Összesen & 104 & 97 & 111 & 91 & 91 & 135 \\
\hline
\end{tabular}

vis, C. conoidea, Nomada alboguttata, N. calimorpha, Epeolus variegatus, Heliophila bimaculata. Ezek a fajok nem a homoktalajhoz, hanem a meleghez és szárazsághoz ragaszkodnak, de a vizsgált területen ez a két igény térben egybe esik. Valódi homokkedvelö faj az Andrena argentata, A. barbilabris, Coelioxys brevis és a Heliophila bimaculata. A fent említett két Nomada faj esetében a lelöhelyek többsége homokvidékeken van, de másutt is elökerültek.

A nedves réteket, magaskórósokat és más fátlan vizes élőhelyeket a fullánkos fajok tulajdonképpen táplálkozás és zsákmányszerzés céljából keresik fel a nyári időszakban. Ezen helyek jelentősége a száraz időszakokban növekszik meg. A Sphecoidea fajok közül a Trypoxylon genusz tagjai, a Crabroninae fajok közül a Crossocerus és az Ectemnius fajok többsége megtalálható itt. Ide járnak táplálkozni az Oxybelus és a Lindenius fajok is. Az itt virágzó Umbelliferae fajokat látogatják még a Nyssoninae alcsaládból a Gorytes fajok és a ritka Lestiphorus bilunulatus. A Philanthinae alcsaládból előfordulnak a Cerceris fajok, a Sphecinae alcsaládból pedig a Sceliphron destillatorium és a Chalybion femoratum. Ezen kívül számos más kaparódarázs jár ezen helyekre nektárért és zsákmányállatért. A Pompilidae család fajainak többsége itt táplálkozik, illetve keresi a pókzsákmányát, de ivadékgondozásuk máshova kötődik. A Scolioidea fajok közül

\section{5. táblázat: Az Apoidea fajok megoszlása családonként, összehasonlítva más területekkel}

\begin{tabular}{|l|c|c|c|c|c|c|}
\hline családok & $\begin{array}{c}\text { Látrányi- } \\
\text { puszta TT. }\end{array}$ & $\begin{array}{c}\text { Baláta-tó TT. és } \\
\text { környéke }\end{array}$ & $\begin{array}{c}\text { Bugac- } \\
\text { puszta }\end{array}$ & $\begin{array}{c}\text { Bátorligeti } \\
\text { TT. }\end{array}$ & $\begin{array}{c}\text { Tihanyi } \\
\text { TK }\end{array}$ & $\begin{array}{c}\text { Zselici } \\
\text { TK. }\end{array}$ \\
\hline Colletidae & 20 & 16 & 19 & 16 & 27 & 26 \\
\hline Andrenidae & 53 & 38 & 21 & 18 & 70 & 84 \\
\hline Halictidae & 51 & 49 & 35 & 51 & 73 & 91 \\
\hline Melittidae & 4 & 3 & 7 & 4 & 5 & 9 \\
\hline Megachilidae & 36 & 35 & 45 & 33 & 78 & 78 \\
\hline Anthophoridae & 27 & 40 & 12 & 22 & 63 & 87 \\
\hline Apidae & 11 & 7 & 12 & 12 & 17 & 15 \\
\hline összesen & 202 & 188 & 151 & 156 & 333 & 390 \\
\hline
\end{tabular}


kevéssel találkozunk a nedves élöhelyeken, ezek a Myrmosa fajok, de alkalmilag ide vetődnek a Smicromyrme fajok, és rendszeresen a Tiphia fajok. A Chrysidoidea fajok többsége - kivéve a kifejezett homokkedvelőket - felkereste ezeket az élőhelyeket. A Vespoidea fajok mintegy felével is találkozhattunk itt. Az Apoidea fajok közül a mocsárrétek, vízpartok lakója a Macropis labiata, $M$. fulvipes. A nyáron repülő Andrena fajok gyakori vendégei a vizes élöhelyeknek, és a Hylaeus fajok többsége szintén. Ezt így tapasztaltuk a vizsgált területen is.

Az arboreális jellegü élőhelyek (erdők, szegélytársulásaik, gyepük, bokorfüzesek) a természetvédelmi területen nagyon mozaikosak. Összefüggőbb állományt csak az erdei és feketefenyő ültetvények alkotnak. Ezek fullánkos faunája olyan szegényes, hogy vizsgálatuktól eltekintettünk. Ezeken az élöhelyeken a Scolioidea, Pompiloidea és Chrysidoidea fajok száma kevés.

A fémdarazsak közül az Omalus és Chrysis fajok kerültek itt elö a xylicol fajok parazitáiként. A pókölö darazsak jellegzetes képviselöi az aljnövényzetben tevékenykedö Priocnemis fajok. A redősszárnyú darazsak közül itt a Vespidae alcsalád tagjai és a Symmorphus gracilis került elö. A Sphecoidea fajok közül a leggyakoribbak itt a Pemphredoninae alcsalád fajai, kivéve a Didontus genuszt. A Crabroninae alcsaládból igen jellemzőek itt a Crossocerus és Ectemnius fajok. A Larrinae alcsalád képviselői pedig a Trypoxylon fajok. Ezek a kaparódarazsak xylicol fajok, tehát a fészkelésük köti öket az arboreális élőhelyekhez. A Nyssoninae alcsaládban a Nysson interruptus, $N$. spinosus és a $N$. trimaculatus kötődik ide. Az Apoidea fajok közül sok Andrena faj repül a tavaszi időszakban az erdei gyepszinten, az erdei szegélytársulásokban, a fészekparazitáikkal a Nomada fajokkal együtt. Megtaláltuk itt a tavaszi Lasioglossum fajokat is. A Megachilidae családból az Osmia fajok a jellemzőek, valamint az Apidae családból a legtöbb Bombus faj.

A gyomtársulások a védett területen többfelé megtalálhatók, különösképpen a Látrány faluval határos szegélyterületen, illetve a területen található kisebb szántókon. Az itt élö gyomflóra sok növénye jó pollen- és nektártermelö, ezért a méhszerü fauna számára jelentős. Az Apoidea taxon fajai kerültek elö innen, illetve megfigyeltük táplálkozásukat. A legtöbb faj az Andrenidae és a Halictidae családból való, de nem elhanyagolható az Apidae és Colletidae fajok látogatása sem. Néhány Anthophoridae faj fó tápnövénye a gyomok közül kerül ki. Például egyes Megachile és Anthidium fajok említhetök meg ezek között. Fontos szerepe van itt a legeltetett területek gyomjainak, például az Ononis spinosanak, Carduus acanthoidesnek.

A faunisztikai szempontból legjelentősebb fajok esetében a fajjegyzékben feltüntettük a dél-dunántúli lelöhelyeik számát. Ezek alapján 7 Scolioidea, 10 Chrysidoidea, 6 Pompiloidea, 4 Vespoidea, 20 Sphecoidea és 17 Apoidea faj mondható kiemelkedően értékesnek. Ebböl az tünik ki, hogy a Vespoidea és az Apoidea taxonokon kívül a többiben a fajok jelentős része mondható színező faunaelemnek. A legjelentősebbekről részletesebb jellemzés készült.

\section{Természetvédelmi javaslatok}

A fullánkos fauna diverzitásának megőrzése érdekében az alábbi kezelési problémákra hívom fel a figyelmet. A darázsfajok fészkelési lehetőségei szempontjából döntő, hogy a nyílt homokgyepek és a szabad homokfelületek fennmaradjanak. Ezeken az öszszességében kis kiterjedésű, mozaikos térszerkezetü területeken nem kívánatosak a szukcessziós folyamatok. Nem káros a kisebb területekre korlátozódó homokfelszín bolygatás, ha az nem jár az agresszív gyomok térhódításával. Az itt öshonos tölgyes visszatelepítése is indokolt lenne a jobb vízellátottságú részeken. A gyomosodó gyepterületeket - melyek sajnos a védett terület több részén is megtalálhatók - rendszeres kaszálni kelle- 


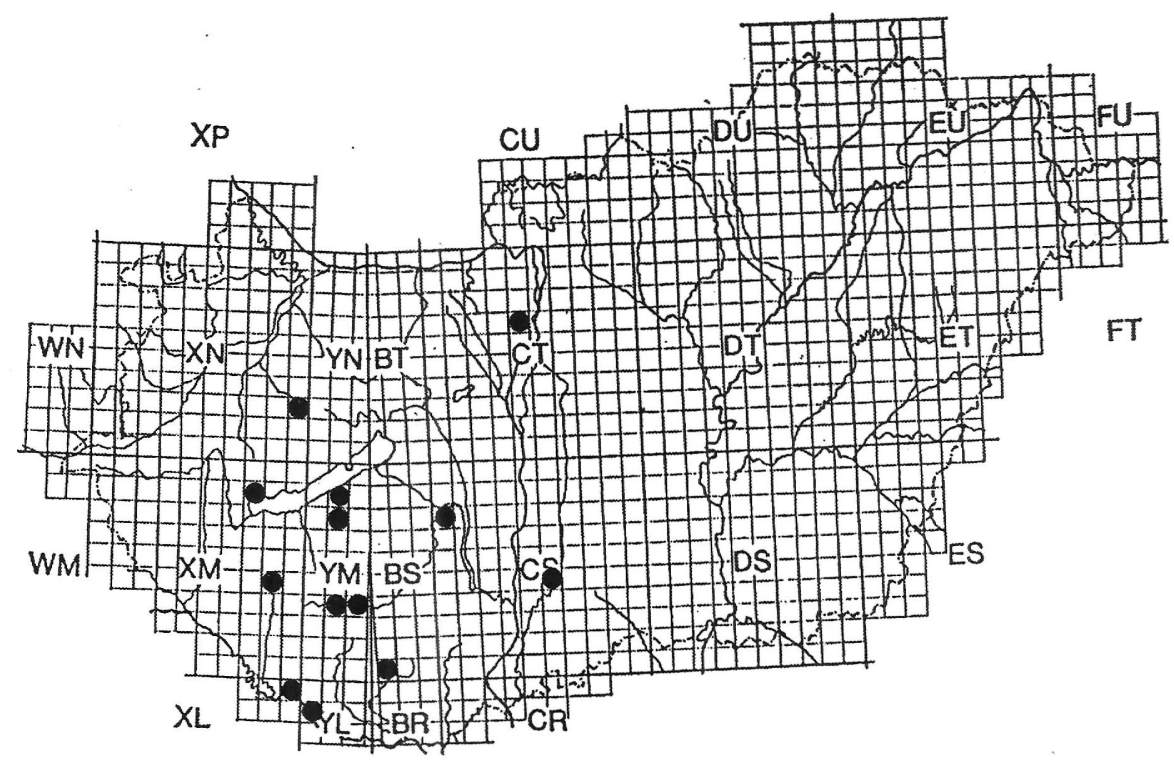

2. ábra: Chrysura trimaculata

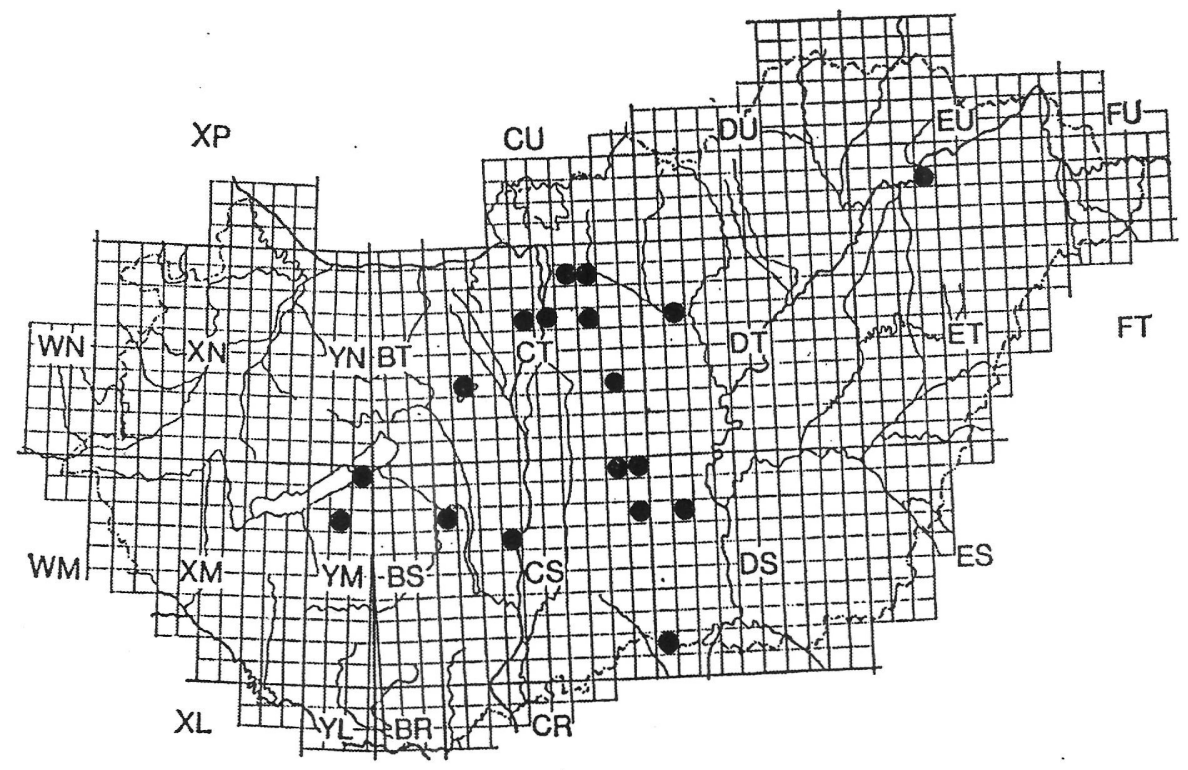

3. ábra: Cerceris fimbriata 


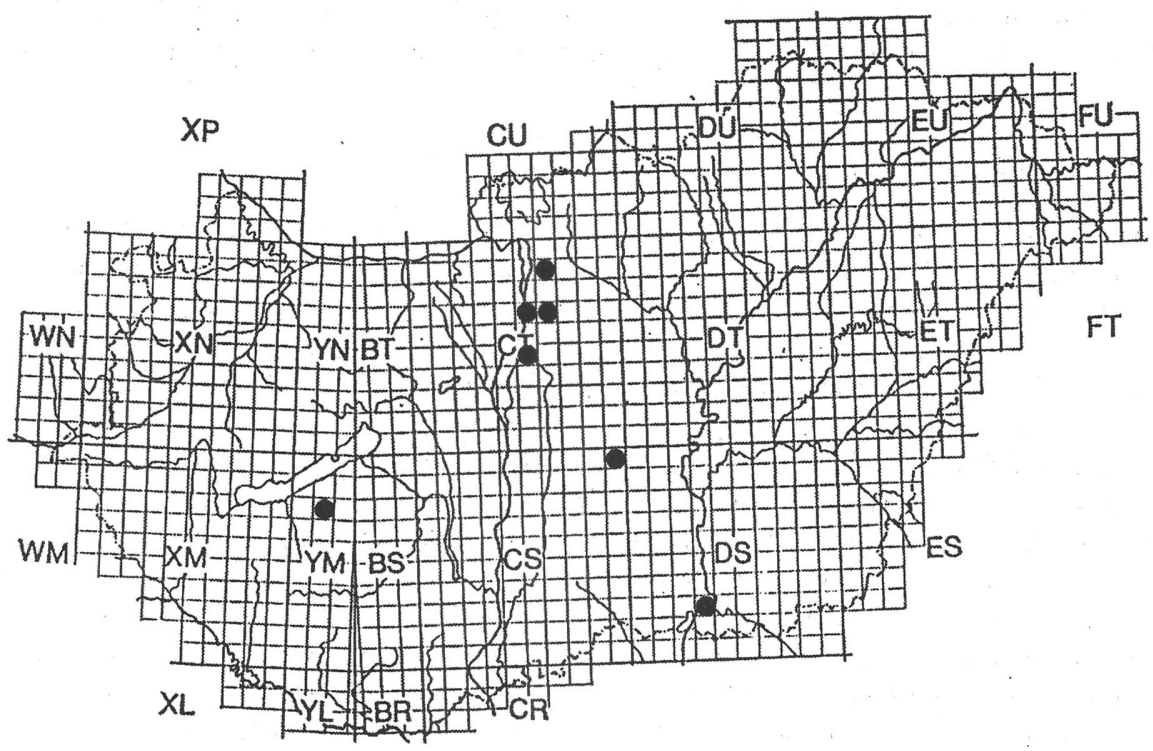

4. ábra: Cerceris somotorensis

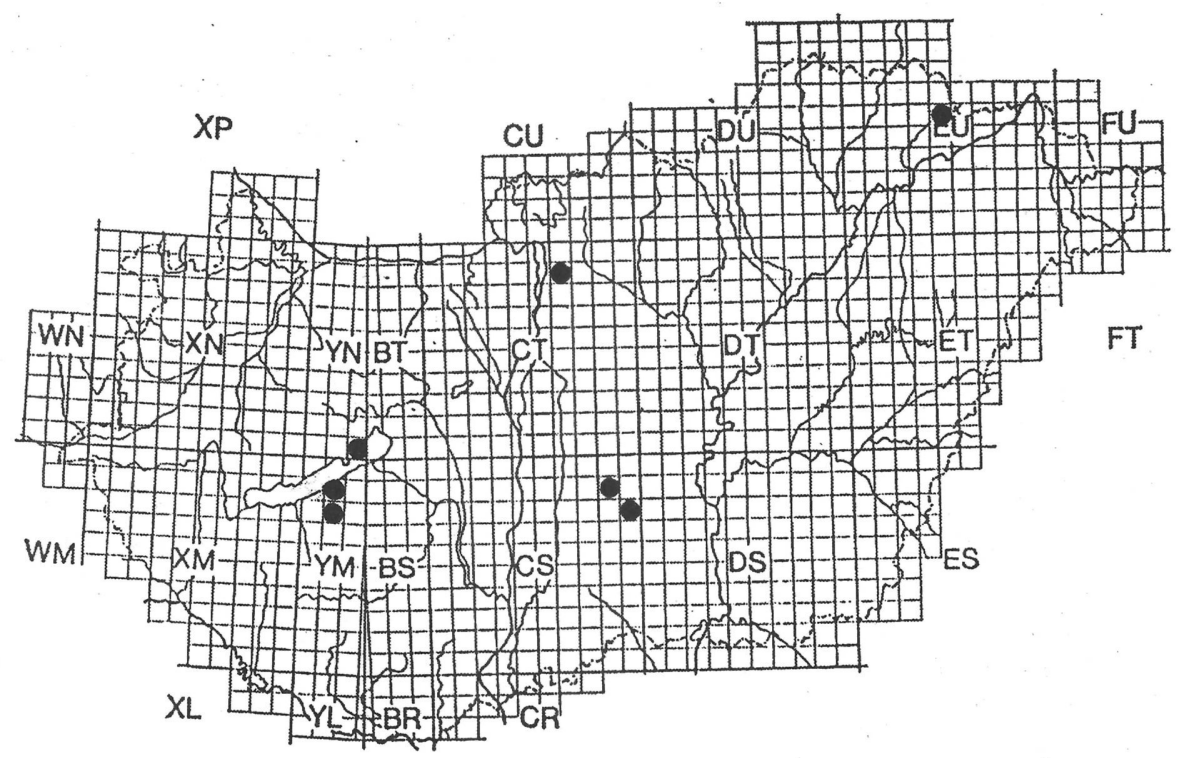

5. ábra: Andrena chrysopus 
ne. A terület egyes részein a veszélyeztető tényező a legeltetés során a szarvasmarhacsorda taposása. Ez a terricol fajok fészkelését veszélyezteti. A védett terület több pontján élő idős nyár és füzfák fennmaradása, elkorhadása a xylicol fajok életlehetőségeit biztosítja.

\section{Néhány ritka faj jellemzése}

Parnopes grandior (Pallas, 1771) - Látrány: Birkás-legelö, 1969. VII. 7., 10"1Q , Látrányi Puszta TT, 1999. VII. 10. 10 (észlelés). - Magyarország homokterületein elterjedt nagy testméretü fémdarázs. A Bembix fajok (Sphecoidea) fészekparazitája. Az Alföldön a leggyakoribbnak a Kiskunságon bizonyult, ahol tíz lelőhelyét közölték (MóczÁr 1986). Elökerült Bátorligeten is (MóczÁr 1990). A Dunántúlon sikerült gyüjtenünk Németkéren, Belső-Somogy több pontján (JóZAN 1992a, 1996a) és a Dráva mentén (JóZAN 1998). Mindenütt kis egyedszámú populációit figyelhettük meg.

Spinolia unicolor (Dahlbom, 1831) - Látrány: Birkás-legelö, 1989. VII. 9., 1O . - Meleghez és szárazsághoz erősen ragaszkodó (stenök eremophil) ritka, palearktikus elterjedésü fémdarázs faj. Hazánkban a Kiskunság néhány pontján és Keszthely környékén (MócZÁr 1967) kívül a Mecsekben (Pécs: Zsebe-domb) és Nagybajom környékén (JóZAN 1992a) sikerült megtalálni ezt a ritka homokkedvelö fémdarázs fajt. Fennmaradása szintén a nyílt homokgyepektől függ.

Chrysura trimaculata (Förster, 1853) - Látrány: Látrányi Puszta TT., 2001. V. 16., $1 \sigma^{\prime}$. - Pontomediterrán elterjedésü kora tavasszal repülő fémdarázs, a csigalakó Osmia fajok fészekparazitája. A régi gyüjtések során elökerült Budapest és Keszthely környékén, Simontornyán és Hajóson (MóczÁR 1967). A szerző megtalálta a Mecsekben, Balatonszemesen és közölte előfordulását a Barcsi borókásból, Bélavár környékéről, Szentborbásról (JóZAN 1995, 1998) és a Zselic két pontjáról (JóZAN 1992b). a Bakonyban Magyarpolányban gyüjtötték (JózAN 1994). A faj ritka, mindenütt csak egy-egy példánya került elő. (1. ábra).

Chrysis angustifrons Abeille, 1878 - Látrány: Birkás-legelö, 1986. VI. 20., 10 - Az elöző fajhoz hasonlóan szintén pontomediterrán elterjedésü, de a nyári aszpektus fémdarázs faja. Magyarországon régebben túlnyomórészt a középhegyvidék déli hegylábi övezetének néhány pontján került elő (MóCZÁR 1967). Dél-Dunántúlon igen ritka, Kaposvár környékén (JózAN 1992b) és a Mecsek két pontján a szerző gyüjtései nyomán került elő. Az utóbbi másfél-két évtizedben nem sikerült gyüjteni.

Eoferreola manticata (Pallas, 1771) - Látrány: Birkás-legelö, 1991. VII. 30., 10", Látrányi puszta TT, 2001. VII. 26., 1\% , Seseli osseum. - Melegkedvelő pontomediterrán pókölődarázs faj. Magyarország alacsonyabb fekvésü tájain került elő, de mindenütt ritka. Dél-Dunántúl védett területeinek kutatása során másutt még nem került elö. Sikerült viszont megtalálnunk a Mecsekben (Tettye), a Balaton-felvidék két pontján és Uzsa környékén. Az eddigi tapasztalatok szerint a sziklagyepeket inkább kedveli, mint a homoki élöhelyeket.

Arachnospila fuscomarginata (Thomson, 1870) - Látrány: Látrányi Puszta TT., 1991. VII. 30., 1Q , 1998. VII. 27., 10", Angelica silvestris. - A régebbi gyüjtések során ez a pókölödarázs faj az Alföld és a középhegyvidék déli részének néhány pontján került elő, Dél-Dunántúlról egyetlen elöfordulását sem ismertük. Az utóbbi évtizedek kutatásai során csak itt a természetvédelmi területen és közvetlen közelében találtuk meg.

Ceropales variegata (Fabricius, 1798) - Látrány: Látrányi Puszta TT., 2001. 07. 25., 1 , Seseli osseum. - A Palearktikum déli részén elterjedt ritka csempészdarázs. Hazánkban túlnyomórészt az Alföldön került elö. A Kiskunsági NP területén csak egy példányát találták meg Szabadszállás környékén (MóczÁr 1986). Dél-Dunántúlon igen ritka, 


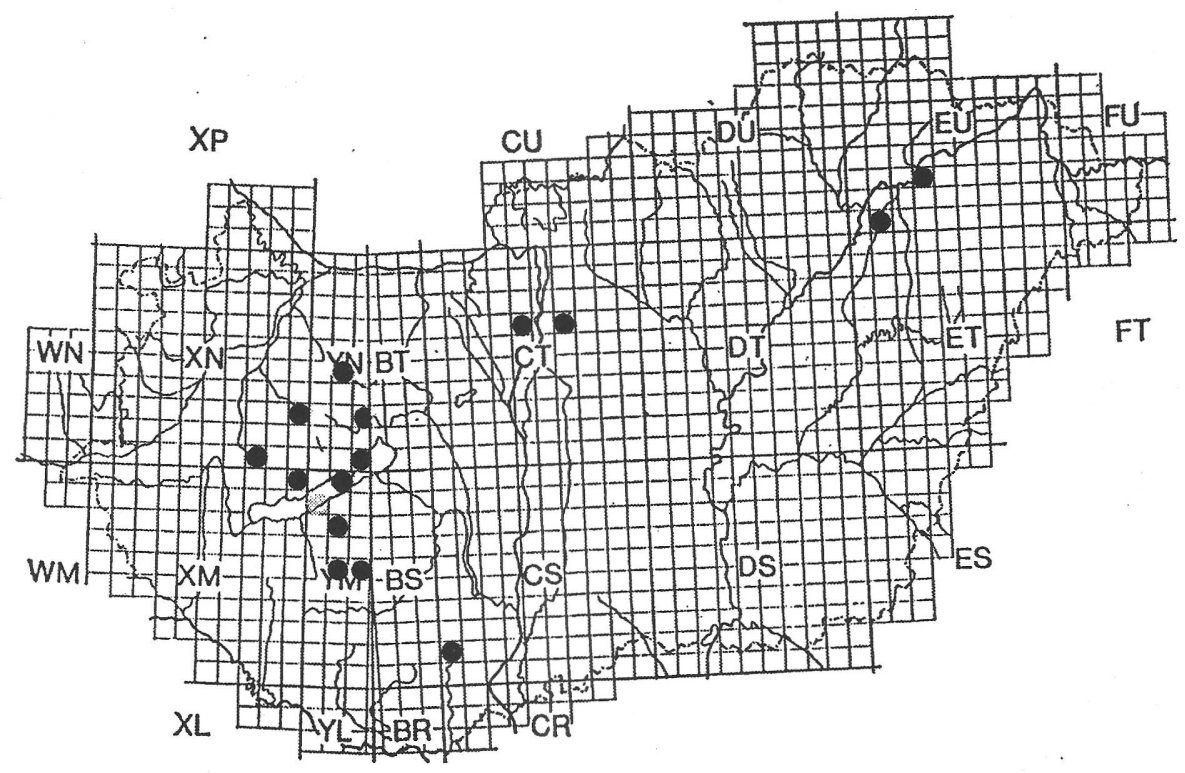

6. ábra: Andrena potentillae

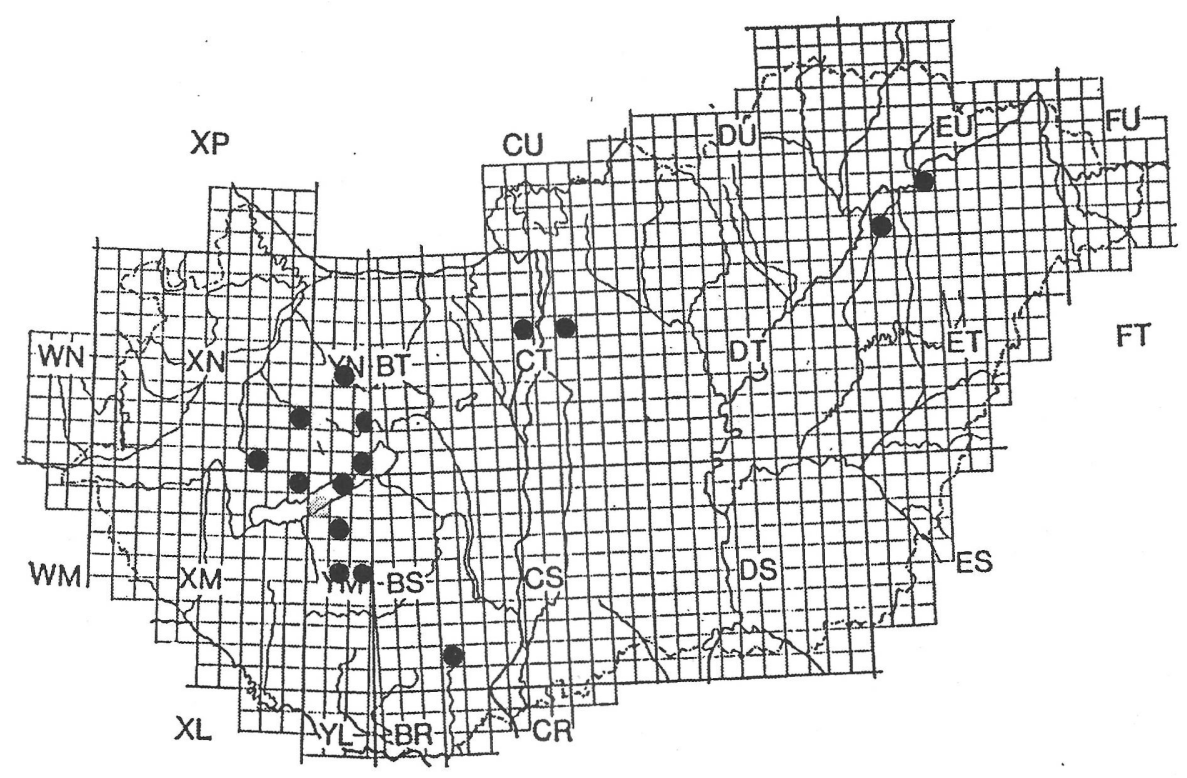

7. ábra: Dioxys tridentata 


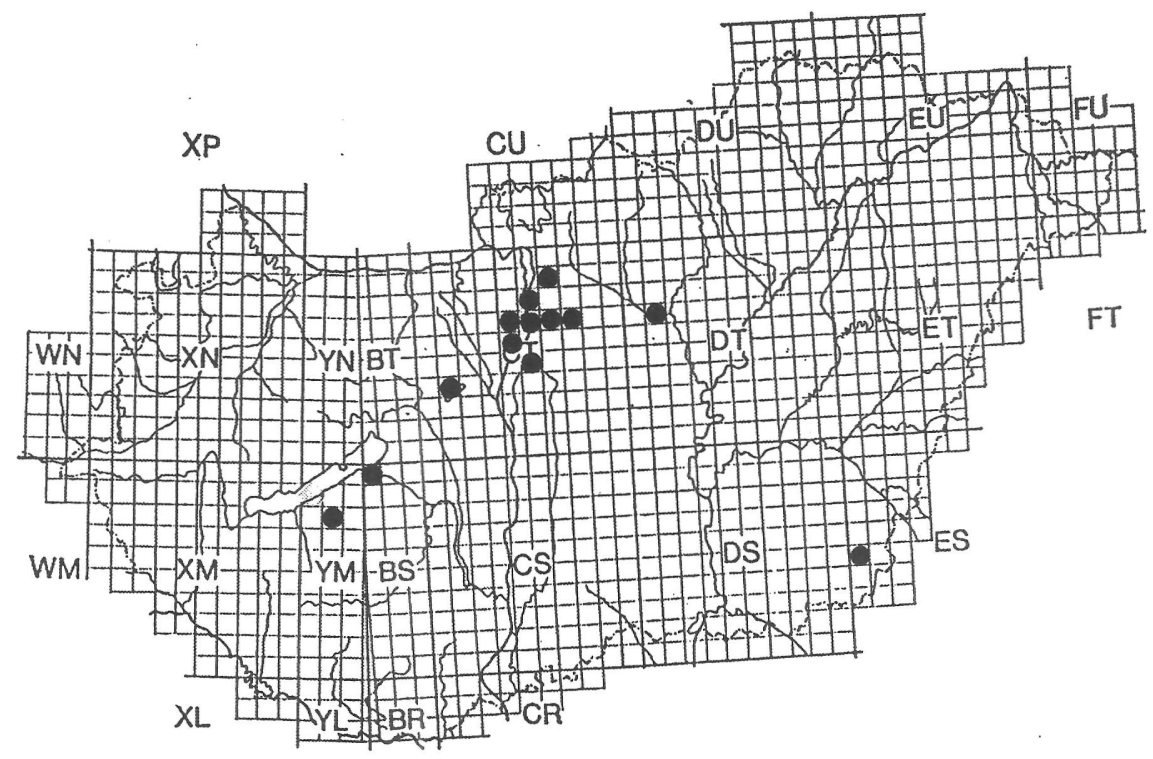

8. ábra: Nomada calimorpha

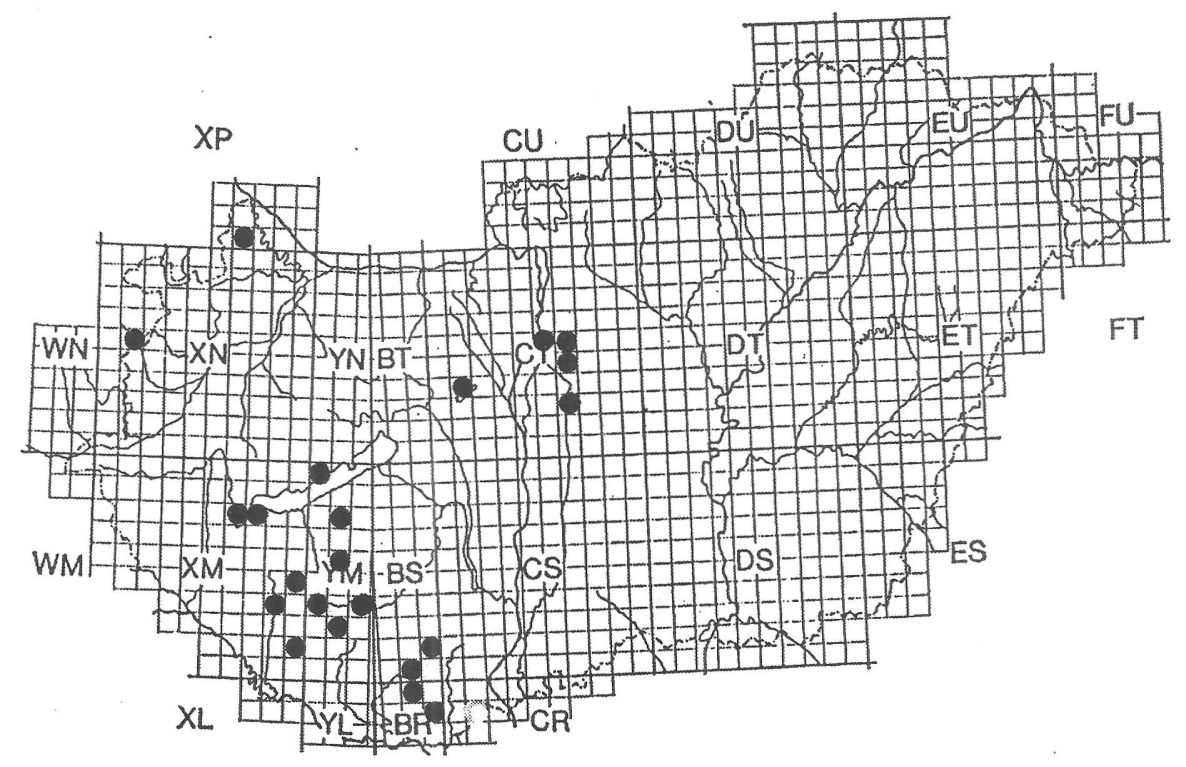


Látrányon kívül csak Ságváron és Orcinál sikerült megtalálnunk.

Belomicrus antennalis Kohl, 1899 - Látrány: Látrányi Puszta TT., 1990. VI. 19., 1Q Igen ritka légyölődarázs faj, melyet Alsó-Ausztriában, a Morva-medence és Dél-Szlovákia néhány pontján kívül a Volga alsó folyása mentén találtak meg. Magyarországon először Örszentmiklóson gyüjtötték (MóczÁR L. 1959). A szerző gyűjtötte még a Fülöpházi buckásban és előkerült a Boronka-melléki TK kutatása során Nagybajom határában (JóZAN 1992a).

Cerceris fimbriata (Rossi, 1790) (=funerea auct. nec Costa 1869) - Látrány: Látrányi puszta TT, 2001. VII. 26., $1 \sigma^{\star}$, Berteroa incana. - Meleghez- és szárazsághoz erősen ragaszkodó (stenök eremophil), mediterrán elterjedésü csomósdarázs faj. A Kárpát-medence alacsonyabb területein is elökerült, de igen ritka. Gyüjtötték Dél-Szlovákiában, a Duna-Tisza köze több pontján Jászberénytől, Örszentmiklóstól a Deliblátihomokvidékig, a Dunántúlon Nadapon, Zamárdiban és Simontornyán. Legkeletebbre Tokajnál került elö (BAJÁRI 1956, BALTHASAR 1972, JóZAN 1986). Dél-Dunántúlon az utóbbi évtizedek gyüjtései során csak itt Látrányban találtuk meg (2. ábra) BAJÁRI (1957) a magyarországi Cerceris fajok határozókulcsában funerea Costa névvel szerepeltette ezt a fajt, ám az általa megadott faji bélyegek a fimbriata fajra illenek. A lunata funerea Costa alfaj és a törzsalakja is Dél-Európában elterjedt, legközelebb a Dalmát tengerparton került elö.

Cerceris somotorensis Balthasar, 1955 (=beaumonti Bajári, 1956) - Látrány: Birkáslegelő, 1976. VI. 28., 2O , Sedum acre. - Ez a Dél-Szlovákiából leírt faj előkerült AlsóAusztriában, Magyarországon, Romániában (Buzias) és Jugoszláviában a Deliblátihomokvidéken (BAJȦRI 1956, BALTHASAR 1972). Nálunk régebben a Kiskunságon és közvetlen környékén került elö. A Dunántúlon csak Látrányból ismerjük elöfordulását (3. ábra).

Andrena chrysopus Pérez, 1903 - Látrány: Birkás-legelö, 1994. V. 28. 20 2Q , Látrányi puszta TT, 2000. VI. 6., 2001. V. 16., 20' 2Q , Asparagus officinalis. - Melegkedvelö pontomediterrán, meglehetősen ritka bányászméh faj. Közép-Európában előkerült Németország déli területeitől Csehországon és Ausztrián át Szlovákiáig (WARNCKE 1986) illetve Romániáig (MóCZÁR és WARNCKE 1972). Nálunk régebben csak a Kiskunságon, Vácdukán és Sátoraljaújhelyen gyüjtötték. A szerző megtalálta Balatonfüreden és Balatonszárszó környékén is (4. ábra).

Andrena potentillae Panzer, 1809 - Látrány: Birkás-legelö. 1991. V. 1., 10̛. - Elterjedése és ökológiai türéshatára az előfajéhoz hasonló. Magyarországon igen szórványosan került elö: Budapest környéke, Tokaj, Hortobágy, a Bakony több pontja, Tihanyi-félsziget, Zengővárkony, Hosszúvíz (Józan 1989, 1992a, 1996b, MóczÁR és WARNCKE 1972). A szerző gyüjtötte még Mernye és Igal határában is. A faj a zárt löszgyepekben, sziklagyepekben és a homokgyepekben egyaránt előfordul a tavasszal virágzó Potentilla fajok virágán.

Dioxys tridentata (Nylander, 1848) - Látrány: Látrányi Puszta TT, 1998. VII. 20., 1O - Európában elterjedt melegkedvelő kétfogú-méh faj. Magyarországon meglehetősen ritka. Lelöhelyeinek többsége a Dunántúlon található: Velencei-hgys., Mecsek (JózAN 1996b), Balaton-felvidék, Németkér és Somogygeszti. Továbbá előkerült még Budapest környékén és Kecskeméten (MóczÁR 1958). Az állatot gazdaállatainak fészkelőhelyein lehet megtalálni, kőfalakon, kőrakásokon, löszpadkákon, nyílt homokgyepben (6. ábra).

Nomada calimorpha Schmiedeknecht, 1882 - Látrány: Birkás. Legelő, 1994. V. 28. , $1 \sigma^{\prime}$ - Igen ritka mediterrán elterjedésü nomádméh. Közép-Európában a Morva-medencében, a Pannon-medence ausztriai, szlovákiai és magyarországi részein került elö (WARNCKE 1986). Hazánkban a 19. század végén és a 20. század elején Budapest mostani közigazgatási területén és közvetlen közelében gyüjtötték (7. ábra). Egy izolált előfordulása van az Alföld délkeleti részén (Dombiratos), a Dunántúlon csak a Velencei-tó- 
Balaton vonalon került elö. A legnyugatabbi előfordulása Látrányi Puszta TT-én van. Bombus argillaceus (Scopoli, 1763) - Látrány: Látrányi Puszta TT., 2001. III. 24., IV. 18., 30' (észlelés) Lamium maculatum. - A mediterrán területeken szélesen elterjedt poszméh. Közép-Európában ritka, csak Svájc, Ausztria és Szlovákia melegebb klímájú tájain fordul elő (WARNCKE 1986). Hazánkban az Alföld néhány pontján, a Budai-hegységben, Magyaróváron, a Mecsekben, a Kőszegi-hegységben, a Kisbalaton térségében és Somogysárdon került elő a régebbi gyüjtések során (MóczÁR 1953). Az utóbbi évtizedekben folytatott kutatások során sikerült megtalálni a Zselicben, Külső- és Belső-Somogyban, a Mecsekben és a Villányi-hegységben (JózAN 1990, 1996b, 2000a, 2000b). az utóbbi egy-másfél évtizedben alig találkoztunk ezzel a védett fajjal, melynek eszmei értéke $50000 \mathrm{Ft}$ (8. ábra).

Bombus paradoxus Dalla Torre, 1882 - Látrány: Birkás-legelö, 1975. V. 13., 10', Vicia grandiflora. - Melegkedvelö pontokaszpikus poszméh. WARNCKE (1986) Közép-Európa hazánktól nyugatra fekvő területeiről nem említi előfordulását. A Kárpát-medencében régebben csak erdélyi és magyarországi előfordulásait közölték (MóCZÁR 1953). A DélDunántúl kutatása során előkerült a Barcsi borókásban, a Zselicben, a Mecsekben és Külső-Somogyban (JózAN 1983, 1990, 1996b, 2000b). Hazai lelöhelyei és az előkerült példányszáma alapján ritkábbnak tünik, mint az előző, a védett állatfajok jegyzékébe bekerült argillaceus.

\section{Összegzés}

A Látrányi Puszta TT. területén és környékén a szerző az 1970-es évektől kezdődően szinte évenként legalább egy alkalommal felkereste ezt a pleisztocén kori homokterületet. 1999-ben és 2001-ben a védett terület egészére kiterjedő részletes faunisztikai feltáró munkát folytatott. A gyüjtőmunka eredményeképpen a vizsgált hat taxonban 403 faj került elö. Ez a terület nagyságát tekintve jelentős példányszám, ami a más vizsgált területekkel való összehasonlitáskor is nyilvánvalóvá vált. A fajok családonkénti és alcsaládonkénti megoszlása azt mutatta, hogy a kaparódarazsak esetében gazdagnak mutatkozott a Sphecinae és a Larrinae alcsalád, míg a méhszerüek körében az Andrenidae és a Halictidae fajok bizonyultak jelentősnek. Az elökerült fajok megoszlását vizsgáltuk elterjedési jellegük és ökofaunisztikai karakterük szerint is. Mind a taxononkénti, mind ez utóbbi szerinti megoszlásuk adatait táblázatokban rögzítettük. A faunisztikai értékek közül említést érdemel a védett fajok jegyzékében szereplö Parnopes grandior, Sphex rufocinctus és a Bombus argicellus. A védett terület faunisztikai értékeit képviseli még azon fajok sora, melyeket a fajjegyzékben dél-dunántúli lelöhelyük számának feltüntetésével külön megjelöltünk. Ez összesen 63 faj. Közöttük természetesen a legjellegzetesebbek a homokkedvelö állatok. A vizsgált terület élöhely típusait négy csoportba osztottuk. Mindegyik csoportot részletesen elemeztük. A faunisztikai szempontból legértékesebb fajok többsége a homoki gyepekben került elö. Emellett a nedvesebb és az arboreális élöhelyeknek is jelentős a fajfenntartó szerepe.

A növények közül a legfontosabb táplálékforrásnak az Euphorbia és az ernyősvirágzatú fajok bizonyultak.

$\mathrm{Az}$ egyes gyüjtöhelyeket részletesen jellemeztük. Készítettünk egy természetvédelmi kezelési javaslatot. A terület a védettséget a fullánkos fauna tekintetében is mindenképpen kiérdemli. 


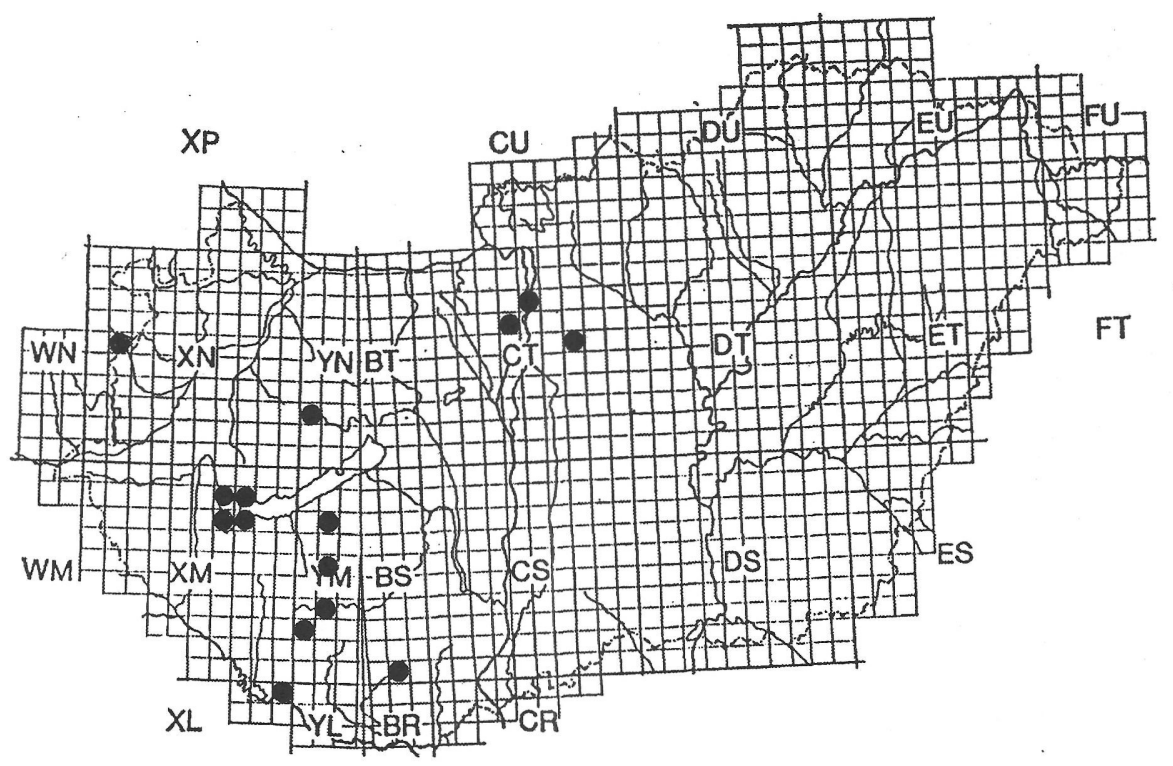

10. ábra: Bombus paradoxus

\section{Irodalom}

BAJÁRı E. 1956: A csomósdarazsak (Cerceris Latr.) faunakatalógusa (Cat. Hym., VIII.). - Folia entomologica hungarica 9: 79-88.

BAJÁRI E. 1957: Kaparódarázs alkatúak I. - Sphecoidea I. - In: Magyarország állatvilága (Fauna Hungariae), XIII/7: 1-117.

Balthasar V. 1972: Grabwespen - Sphecoidea, Fauna CSSR. 20., Verlag der Tshchosl. Akad. Der Wissensch., Praha: 1-471.

JózAN Zs. 1983: A Barcsi borókás fullánkos (Hymenoptera, Aculeata) faunája, I. - Dunántúli Dolgozatok Természettudományi Sorozat, 3: 89-113.

JózAn Zs. 1986: The Scolioidea and Sphecoidea fauna of the Kiskunság National Park (Hymenoptera). - In. Mahunka, S. (ed.): The Fauna of the Kiskunság National Park, 1., Akadémiai Kiadó, Budapest: 365-381.

JózAN Zs. 1989: A Tihanyi Tájvédelmi Körzet fullánkos faunája (Hymenoptera, Aculeata), I. Folia Musei Historico-naturalis Bakonyiensis, 8: 79-110.

JózAn Zs. 1990: A Zselic méhszerü (Hymenoptera, Apoidea) faunájának alapvetése. - A Janus Pannonius Múzeum Évkönyve, 34 (1989): 81-92.

JózAN Zs. 1992a: A Boronka-melléki Tájvédelmi körzet fullánkos hártyásszárnyú (Hymenoptera, Aculeata) faunájának alapvetése - Dunántúli Dolgozatok Természettudományi Sorozat. 7: 163-210.

JózAN Zs. 1992b: A Zselic darázsfaunájának (Hymenoptera, Aculeata) állatföldrajzi és ökofaunisztikai vizsgálata. - Somogyi Múzeumok Közleményei, 9: 279-292.

JózAN Zs. 1994: A Bakony fémdarázs faunájának (Hymenoptera, Chrysididae) alapvetése. - Folia Musei Historico-naturalis Bakonyiensis, 13 (1998): 117-134.

JózAN Zs. 1995: Adatok a tervezett Duna-Dráva Nemzeti Park fullánkos hártyásszárnyú (Hymenoptera, Aculcata) faunájának ismeretéhez. - Dunántúli Dolgozatok Természettudományi Sorozat, 8: 99-115.

JózAN Zs. 1996a: A Baláta környék fullánkos hártyásszárnyú faunájának (Hym., Aculeata) alapvetése. - Somogyi Múzcumok Közleményci, 12: 271-297.

JózAN Zs. 1996b: A Mecsek méhszerü faunája (Hymenoptera, Apoidea). - A Janus Pannonius Múzeum Évkönyve, 40 (1995): 29-43. 
Józan Zs. 1998: A Duna-Dráva Nemzeti Park fullánkos hártyásszárnyú (Hymenoptera, Aculeata) faunája. Dunántúli Dolgozatok Természettudományi Sorozat, 9: 291-327.

JózAN Zs. 2000a: A Villányi-hegység fullánkos hártyásszárnyú (Hymenoptera: Aculcata) faunája. - Dunántúli Dolgozatok Természettudományi Sorozat, 10: 267-283.

JózAN Zs. 2000b: Külsö-Somogy méhszerü (Hymenoptera, Apoidea) faunája. - Somogyi Múzcumok Közleményei, 14: 308-330.

MóCZÁR L. 1967: Fémdarázsalkatúak. - Chrysidoidea. - In: Magyarország Állatvilága (Fauna Hungariae), $\mathrm{XIII} / 2 .: 1-118$.

MóczÁr L. 1986: The survey of the Chrysidoidea, Pompiloidea and Vespoidea Fauna of the Kiskunság National Park (Hymenoptera). - In. Mahunka, S. (ed.): The Fauna of the Kiskunság National Park, 1., Akadémiai Kiadó, Budapest: 383-400.

MóczÁR L. 1990: Further data to the Chrysidoidea, Pompilioidea and Vespoidea fauna (Hymenoptera) of the Bátorliget Nature Reserves. - In: The Bátorliget Nature Reserves - after forty years, Magyar Természettudományi Múzcum, Budapest: 623-632.

MóczÁr M. 1953: A Dongóméhek (Bombus Latr.) faunakatalógusa. (Cat. Hym., IV.) - Folia entomologica hungarica, 6(5): 197-228.

MóczȦr M. 1958: Müvészméhek. - Megachilidac. - In: Magyarország Állatvilága (Fauna Hungariac), XIII/12.: 1-78.

MÓCZÁr L., WARNCKE K. 1972: Faunenkatalog der Gattung Andrena Fabricius (Cat. Hym., XXVI.). - Acta biologica Szeged, 18: 185-221.

WARNCKE K. 1986: Dic Wildbienen Mitteleuropas ihre gültigen Namen und ihre Verbreitung (Insecta: Hymenoptera), - Entomofauna, Zcitschrift für Entomologie, Suppl. 3: 1-128.

\section{6. táblázat: A Látrányi puszta természetvédelmi területén elökerült fullánkos fajok}

A = száraz gycpek

$\mathrm{B}=$ mocsárrétek, magaskórósok

$\mathrm{C}=$ erdöszegélyek, gyepük, füzesek

Taxonok

SCOLOIDEA (sensu lato)

Scolia hirta (Schrk.)

Scolia quadripunctata (Fabr.)

Campsoscolia sexmaculata (Fabr.)

Tiphia femorata Fabr.

Tiphia morio Fabr.

Tiphia ruficornis Klug

Meria tripunctata (Rossi)

Myrmosa brunnipes Lep.

Myrmosa melanocephala (Fabr.)

Smicromyrme cingulata Costa

Smicromyrme halensis (Fabr.)

Smicromyrme rufipes (Fabr.)

Smicromyrme sicana Dest.

Dasylabris regalis (Fabr.)

CHRYSOIDEA

Cleptes semiauratus (L.)

Elampus scutellaris (Pz.)

Omalus aeneus (Fabr.)

Pseudomalus auratus (L.)

Pseudomalus pusillus (Fabr.)
$\mathrm{D}=$ gyomtársulások

$\mathrm{E}=$ lelöhelyeinek száma Dél-Dunántúlon 


\begin{tabular}{|c|c|c|c|c|}
\hline Pseudomalus violaceus (Scop.) & + & & & 4 \\
\hline Holopyga amoenula Dahlb. & & + & & \\
\hline Holopyga fervida (Fabr.) & + & & & \\
\hline Hedychrum gerstaeckeri Chevr. & + & + & & \\
\hline Hedychrum rutilans (Dhlb.) & + & + & & \\
\hline Hedychrum nobile (Scop.) & + & & & \\
\hline Hedychridium ardens (Coqu.) & + & & & \\
\hline Hedychridium coriaceum (Dhlb.) & + & + & & \\
\hline Hedychridium jucundum (Mocs.) & + & & & \\
\hline Hedychridium roseum (Rossi) & + & + & & \\
\hline Parnopes grandior (Pall.) & + & & & 9 \\
\hline Spinolia unicolor (Dhlb.) & + & & & 3 \\
\hline Chrysis angustifrons (Ab.) & + & & & 4 \\
\hline Chrysis fulgida $\mathrm{L}$. & + & + & & \\
\hline Chrysis gracillima $\mathrm{F} \quad$ rst. & & $\square$ & + & \\
\hline Chrysis ignita L. & & + & & \\
\hline Chrysis indigotea (Duf. Et Perr.) & & & + & \\
\hline Chrysis pulchella Spin. & + & $\rightarrow$ & - & 9 \\
\hline Chrysis rutilans Oliv. & & + & + & \\
\hline Chrysis rutiliventris $\mathrm{Ab}$. & + & + & & \\
\hline Chrysis splendidula Rossi & + & & & 2 \\
\hline Chrysis succincta L. & + & & & \\
\hline Chrysis compta $\mathrm{F}$ & & + & & 5 \\
\hline Trichysis cyanea (L.) & + & + & + & \\
\hline Chysura trimaculata (Rossi) & + & - & & 8 \\
\hline \multicolumn{5}{|l|}{ POMPILOIDEA } \\
\hline Cryptocheilus fabricii (Lind.) & + & + & & 6 \\
\hline Cryptocheilus notatus affinis (Lind.) & 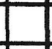 & + & & + \\
\hline Priocnemis coriacea Dhlb. & + & + & + & \\
\hline Priocnemis gracilis Hpt. & + & + & & 7 \\
\hline Priocnemis hyalinata (Fabr.) & + & + & + & \\
\hline Priocnemis melanosoma Kohl & & + & & \\
\hline Priocnemis perturbator (Harr.) & + & + & + & \\
\hline Priocnemis pusilla Schdte. & & + & & \\
\hline Caliadurgus fasciatellus (Spin.) & + & & & \\
\hline Auplopus carbonarius (Scop.) & + & + & & \\
\hline Eoferreola manticata (Pall.) & + & $\square$ & & 3 \\
\hline Homonotus balcanicus Hpt. & + & + & & \\
\hline Pompilus cinereus (Fabr.) & + & & & \\
\hline Arachnospila abnormis (Dhlb.) & + & & & \\
\hline Arachnospila anceps (Wesm.) & & + & & \\
\hline Arachnospila fuscomarginata (Zett.) & + & + & & 1 \\
\hline Arachnospila minutula (Dhlb.) & + & + & & \\
\hline Arachnospila spissa (Schdte.) & + & & & \\
\hline Arachnospila trivialis (Dhlb.) & + & + & & \\
\hline Arachnospila wesmaeli Ths. & + & & & \\
\hline Aporinellus sexmaculatus (Spin.) & + & & & 11 \\
\hline Evagetes littoralis (Wesm.) & + & & & \\
\hline Evagetes pectinipes (L.) & + & & & \\
\hline Evagetes gibbulus (Lep.) & & + & & \\
\hline
\end{tabular}




\section{6. táblázat: folytatás}

\begin{tabular}{|c|c|c|c|c|c|}
\hline Evagetes siculus (Lep.) & & + & & & \\
\hline Anoplius caviventris (Aur.) & & + & & & \\
\hline Anoplius infuscatus (Lind.) & + & & & & \\
\hline Anoplius nigerrimus (Scop.) & & + & + & & \\
\hline Anoplius viaticus paganus (Dhlb.) & + & & & & \\
\hline Episyron arrogans (Sm.) & & + & & & \\
\hline Episyron rufipes (L.) & + & & & & \\
\hline Episyron albonotatus (Lind.) & + & + & & & \\
\hline Ceropales maculata (Fabr.) & & + & & & \\
\hline Ceropales variegata (Fabr.) & + & & & & 3 \\
\hline \multicolumn{6}{|l|}{ VESPOIDEA } \\
\hline Vespa crabro $\mathrm{L}$. & & & + & & \\
\hline Vespula germanica $\left(\mathrm{F}_{\mathrm{.}}\right)$ & & + & + & & \\
\hline Polistes associus Kohl & + & 7 & 7 & & 1 \\
\hline Polistes nympha (Christ) & + & + & + & + & \\
\hline Polistes omissus (Weyr.) & + & & & & 2 \\
\hline Odynerus poecilus (Sauss.) & + & & & & \\
\hline Pterocheilus phaleratus (Pz.) & + & & & & 8 \\
\hline Pseudomicrodynerus parvulus (H. Sch.) & + & & & & \\
\hline Microdynerus nugdunensis (Sauss.) & & + & & & \\
\hline Leptochilus regulus (Sauss.) & & + & & & \\
\hline Euodynerus notatus (Jur.) & & + & & & \\
\hline Stenodynerus chevrieranus (Sauss.) & + & & & & \\
\hline Allodynerus rossii (Lep.) & & + & & & 11 \\
\hline Parodontodynerus ephippium (Klug) & + & & & & \\
\hline Jucancistrocerus jucundus (Mocs.) & & + & & & \\
\hline Symmorphus gracilis (Br.) & & & + & & \\
\hline Eumenes coarctatus (L.) & + & + & + & & \\
\hline Eumenes papillarius (Christ) & & + & & & \\
\hline Eumenes pedunculatus $(\mathrm{Pz})$. & + & + & & & \\
\hline \multicolumn{6}{|l|}{ SPHECOIDEA } \\
\hline Sceliphron destillatorium (Ill.) & + & + & & & \\
\hline Chalybion femoratum (Fabr.) & & + & & & \\
\hline Sphex rufocinctus Br. & + & & & & \\
\hline Prionyx kirbyi (Lind.) & + & & & & \\
\hline Ammophila campestris Latr. & + & & & & \\
\hline Ammophila heydeni Dhlb. & + & & & & \\
\hline Ammophila sabulosa (L.) & + & & + & & \\
\hline Ammophila terminata mocsaryi Friv. & + & & & & 12 \\
\hline Podalonia affinis (K.) & + & & & & \\
\hline Podalonia luffi (Saund.) & + & & & & 4 \\
\hline Mimesa sp. & + & & & & \\
\hline Psenulus laevigatus (Schck.) & & & + & & \\
\hline Psenulus pallipes (Pz.) & + & + & + & & \\
\hline Psenulus schencki (Tourn.) & + & & & & \\
\hline Pemphredon inornatus Say & & + & + & & \\
\hline Pemphredon lethifer (Shuck.) & + & + & + & & \\
\hline Diodontus luperus Schck. & & +1 & & & \\
\hline
\end{tabular}




\begin{tabular}{|c|c|c|c|c|c|}
\hline Diodontus major Kohl & + & & & & 2 \\
\hline Diodontus minutus (Fabr.) & + & + & & + & \\
\hline Passaloecus insignis (Lind.) & & & + & & \\
\hline Passaloecus singularis Dhlb. & & & + & & \\
\hline Stigmus pendulus $\mathrm{Pz}$. & & & + & & \\
\hline Stigmus solskyi Mor. & & & + & & \\
\hline Astata boops (Schrk.) & + & & & & \\
\hline Astata kashmirensis Nurse & & + & & & \\
\hline Astata minor Kohl & + & & & & \\
\hline Dinetus pictus (Fabr.) & + & & & & \\
\hline Tachytes etruscus (Rossi) & + & & & & 6 \\
\hline Tachytes europaeus Kohl & + & & & & \\
\hline Tachysphex fulvitarsis (Costa) & + & & & & \\
\hline Tachysphex helveticus Kohl & + & & & & \\
\hline Tachysphex nitidus (Spin.) & + & + & & & \\
\hline Tachysphex obscuripennis (Schck.) & + & & & & \\
\hline Tachysphex panzeri (Lind.) & + & & & & 5 \\
\hline Tachysphex pompiliformis (Spin.) & + & + & & & \\
\hline Tachysphex psammobius (Kohl) & + & & & & \\
\hline Tachysphex grandii Beaum. & + & & & & 7 \\
\hline Palarus variegatus (F.) & + & & & & \\
\hline Larra anathema (Rossi) & & + & & & 7 \\
\hline Mischopus bicolor Jur. & + & & & & \\
\hline Mischopus spurius (Dhlb.) & + & & 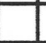 & & \\
\hline Trypoxylon attenuatum $\mathrm{Sm}$. & & + & + & & \\
\hline Trypoxylon clavicerum Lep.et Serv. & & + & + & & \\
\hline Trypoxylon figulus (L.) & + & + & + & & \\
\hline Trypoxylon fronticorne Guss. & & + & & & 6 \\
\hline Belomicrus antennalis Kohl & + & & . & & 1 \\
\hline Oxybelus bipunctatus Oliv. & + & + & & & \\
\hline Oxybelus lineatus (Fabr.) & + & & & & 2 \\
\hline Oxybelus quattordecimnotatus Jur. & + & + & & & \\
\hline Oxybelus uniglumis (L.) & + & + & & & \\
\hline Oxybelus variegatus Wesm. & + & + & & & \\
\hline Oxybelus victor Lep. & + & & T. & & \\
\hline Entomognathus brevis (Lind.) & & 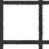 & + & & \\
\hline Lindenius albilabris (Fabr.) & + & + & + & & \\
\hline Lindenius panzeri (Lind.) & + & + & & & \\
\hline Lindenius parkanensis Zav. & & + & & & \\
\hline Crossocerus cetratus (Schck.) & & + & & & \\
\hline Crossocerus podagricus (Lind.) & & + & + & & \\
\hline Crossocerus quadrimaculatus (Fabr.) & + & + & + & & \\
\hline Crossocerus vagabundus (Pz.) & & & + & & 12 \\
\hline Crossocerus elongatulus (Lind.) & & + & & & \\
\hline Ectemnius cavifrons (Ths.) & & + & & & \\
\hline Ectemnius cephalotes (Oliv.) & & + & & & \\
\hline Ectemnius confinis (Walk.) & & + & + & & \\
\hline Ectemnius continuus (Fabr.) & & + & + & & \\
\hline Ectemnius dives (Lep.et $\mathrm{Br}$.) & & & + & & \\
\hline Ectemnius fossorius (L.) & & + & & & \\
\hline
\end{tabular}




\section{6. táblázat: folytatás}

\begin{tabular}{|c|c|c|c|c|c|}
\hline Ectemnius lapidarius (Pz.) & + & + & + & & \\
\hline Ectemnius lituratus (Pz.) & & + & & & \\
\hline Ectemnius meridionalis (Costa) & & + & & & 10 \\
\hline Ectemnius rubicola (Duf. et Perr.) & + & + & + & & \\
\hline Ectemnius rugifer (Dhlb.) & & + & & & \\
\hline Ectemnius nigritarsus (H. Sch.) & & + & & & 7 \\
\hline Lestica alata $(\mathrm{Pz})$. & + & & & & \\
\hline Lestica clypeata (Schreb.) & + & + & & & \\
\hline Crabro peltarius (Schreb.) & + & & + & & \\
\hline Crabro cribrarius (L.) & + & + & & & \\
\hline Alysson spinosus (Pz.) & + & + & & & \\
\hline Argogorytes fargeii (Shuck.) & + & & . & & 4 \\
\hline Nysson dimidiatus Jur. & + & & + & & \\
\hline Nysson interruptus (Fabr.) & & & + & & \\
\hline Nysson maculosus (Gmel.) & & + & & & \\
\hline $\begin{array}{ll}\text { Nysson spinosus (F } & \text { rst.) }\end{array}$ & + & & + & & \\
\hline Nysson trimaculatus (Rossi) & & + & + & & \\
\hline Dienoplus elegans (Lep.) & + & & - & & \\
\hline Lestiphorus bilunulatus Costa & + & + & 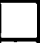 & & 9 \\
\hline Gorytes fallax Handl. & & + & + & & \\
\hline Gorytes laticinctus (Lep.) & + & + & & & \\
\hline Gorytes quadrifasciatus (Fabr.) & + & + & & & \\
\hline Gorytes quinquecinctus (Fabr.) & + & + & & & \\
\hline Mellinus arvensis (L.) & + & & 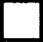 & & \\
\hline Bembecinus tridens (F.) & + & + & + & & \\
\hline Bembix megerlei Dhlb. & + & & & & 1 \\
\hline Bembix rostrata (L.) & + & & & & \\
\hline Bembix tarsata Latr. & + & & & & \\
\hline Philanthus coronatus (Thunb.) & + & & & & 7 \\
\hline Philanthus triangulum (F.) & + & + & & & \\
\hline Cerceris albofasciata (Rossi) & + & + & & & \\
\hline Cerceris arenaria (L.) & + & + & + & & \\
\hline Cerceris fimbriata (Rossi) & + & & & & 1 \\
\hline Cerceris quinquefasciata (Rossi) & + & + & & & \\
\hline Cerceris sabulosa (Pz.) & + & + & & + & \\
\hline Cerceris somotorensis Balth. & + & & & & 1 \\
\hline \multicolumn{6}{|l|}{ APOIDEA } \\
\hline \multicolumn{6}{|l|}{ Colletidae } \\
\hline Hylaeus annularis (K.) & + & + & & & \\
\hline Hylaeus brevicornis Nyl. & + & + & + & + & \\
\hline Hylaeus communis Nyl. & & + & + & & \\
\hline Hylaeus cornutus Curt. & & + & & & \\
\hline Hylaeus duckei Alfk. & + & + & & & \\
\hline Hylaeus gibbus confusus Nyl. & & + & + & + & \\
\hline Hylaeus leptocephalus (Mor.) & & + & & + & \\
\hline Hylaeus punctatus $\mathrm{F}$ & & + & & & \\
\hline Hylaeus punctulatissimus Sm. & + & & & & \\
\hline Hylaeus signatus (Pz.) & & & & + & \\
\hline
\end{tabular}




\begin{tabular}{|c|c|c|c|c|c|}
\hline Hylaeus sinuatus (Schck.) & & + & & +1 & \\
\hline Hylaeus styriacus $\mathbf{F} \quad$ rst. & & + & + & & \\
\hline Hylaeus variegatus (Fabr.) & + & + & & & \\
\hline Colletes cunicularius (L.) & + & & & + & \\
\hline Colletes daviesanus $\mathrm{Sm}$. & & + & & & \\
\hline Colletes fodiens (Geoffr.) & + & + & & & \\
\hline Colletes hylaeiformis Ev. & + & & & & \\
\hline Colletes marginatus Sm. & + & & & & 5 \\
\hline Colletes pallescens Nosk. & + & & & & 8 \\
\hline Colletes similis Schck. & & + & & & \\
\hline Andrenidae & & & & & \\
\hline Andrena alfkenella Perk. & + & & & + & \\
\hline Andrena argentata $\mathrm{Sm}$. & + & & + & & \\
\hline Andrena barbilabris (K.) & + & & & & \\
\hline Andrena bicolor Fabr. & & & + & & \\
\hline Andrena bimaculata bimaculata (K.) & & & + & & \\
\hline Andrena bisulcata Mor. & & & 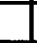 & + & \\
\hline Andrena bucephala Perk. & & & + & & \\
\hline Andrena carbonaria (L.) & + & & & + & \\
\hline Andrena chrysopus P & + & & & - & 2 \\
\hline Andrena chrysopyga Schck. & + & & & + & \\
\hline Andrena cordialis Mor. & & + & & + & \\
\hline Andrena curvana War. & & + & & & \\
\hline Andrena dorsata dorsata $(\mathrm{K})$. & + & & & + & \\
\hline Andrena falsifica Perk. & + & & & 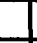 & \\
\hline Andrena flavipes $\mathrm{Pz}$. & + & + & + & + & \\
\hline Andrena floricola Ev. & + & & & + & \\
\hline Andrena florivaga Ev. & + & & & 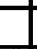 & 6 \\
\hline Andrena fulvicornis Schck. & 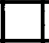 & + & & & \\
\hline Andrena gravida Imh. & & & + & & \\
\hline Andrena haemorrhoa (Fabr.) & & & + & & \\
\hline Andrena helvola (L.) & & & + & & \\
\hline Andrena labilalis (K.) & + & & & & \\
\hline Andrena labiata $\mathrm{F}$. & + & + & & 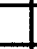 & \\
\hline Andrena minutula (K.) & & + & & + & \\
\hline Andrena minutuloides Perk. & & + & & + & \\
\hline Andrena mocsaryi Schmdk. & + & & & & \\
\hline Andrena nigroaenea $(\mathrm{K})$. & & & & + & \\
\hline Andrena nitida nitida (M & + & 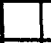 & + & + & \\
\hline Andrena nitida limata $\mathrm{Sm}$. & + & + & & & \\
\hline Andrena nitidiuscula Schck. & + & + & & & \\
\hline Andrena nobilis Mor. & + & & & & 8 \\
\hline Andrena numida hypopolia Schmdk. & + & & & & 6 \\
\hline Andrena nychtemera Imh. & & & + & & \\
\hline Andrena ovatula (K.) & + & + & & & \\
\hline Andrena paucisquama Nosk. & + & & & & \\
\hline Andrena potentillae $\mathrm{Pz}$. & + & & & & 4 \\
\hline Andrena praecox (Scop.) & & & + & & \\
\hline Andrena proxima (K.) & + & & + & + & \\
\hline Andrena rosae $\mathrm{Pz}$. & & + & + & & \\
\hline
\end{tabular}




\section{6. táblázat: folytatás}

\begin{tabular}{|c|c|c|c|c|c|}
\hline Andrena rufula Schmdk. & & & + & & 7 \\
\hline Andrena saxonica $\mathrm{St}$ & + & & + & & \\
\hline Andrena schencki Mor. & + & & & & \\
\hline Andrena schlettereri Fr. & & & & + & \\
\hline Andrena simontornyella Nosk. & & & + & + & \\
\hline Andrena suerinensis Fr. & & & & + & \\
\hline Andrena susterai Alfk. & + & & + & & \\
\hline Andrena symphyti Schmdk. & & + & & & \\
\hline Andrena taraxaci Gir. & + & & + & & \\
\hline Andrena tibialis $(\mathrm{K})$. & & & + & & \\
\hline Andrena vaga $\mathrm{Pz}$. & + & & + & & \\
\hline Andrena viridescens Vier. & & + & & & \\
\hline Andrena ventralis Imh. & & & + & & \\
\hline Panurgus calcaratus (Scop.) & + & & & & \\
\hline Halictidae & & & & & \\
\hline Halictus (Halictus) langobardicus $\mathrm{Bl}$ & + & & & & \\
\hline Halictus (Halictus) maculatus Sm. & + & & & + & \\
\hline Halictus (Halictus) rubicundus (Christ) & + & & & & \\
\hline Halictus (Halictus) simplex Bl & + & + & & + & \\
\hline Halictus (Halictus) sexcinctus (Fabr.) & + & & & & \\
\hline Halictus (Seladonia) confusus perkinsi $\mathrm{Bl}$ & + & & + & & \\
\hline Halictus (Seladonia) leucaheneus arenosus Ebmer & + & & & & \\
\hline Halictus (Seladonia) semitectus Mor. & + & & & & \\
\hline Halictus (Seladonia) subauratus (Rossi) & + & & & & \\
\hline Halictus (Seladonia) tumulorum (L.) & + & & & & \\
\hline Lasioglossum (Lasioglossum) discum (Sm.) & + & & & & \\
\hline Lasioglossum (Lasioglossum) laevigatum (K.) & + & & + & + & \\
\hline Lasioglossum (Lasioglossum) laterale (Br.) & + & & & + & \\
\hline Lasioglossum (Lasioglossum) leucozonium (Schrk.) & + & + & & + & \\
\hline Lasioglossum (Lasioglossum) quadrinotatum (K.) & + & & & & \\
\hline Lasioglossum (Lasioglossum) sexnotatum (K.) & + & + & + & + & \\
\hline Lasioglossum (Lasioglossum) xanthopum (K.) & + & & & + & \\
\hline Lasioglossum (Lasioglossum) zonulum (Sm.) & + & + & & + & \\
\hline Lasioglossum (Evylaeus) albipes (Fabr.) & + & & & + & \\
\hline Lasioglossum (Evylaeus) brevicorne brevicorne (Schck.) & + & & & + & \\
\hline Lasioglossum (Evylaeus) brevicorne aciculatum (B1 .) & + & & & & \\
\hline Lasioglossum (Evylaeus) calceatum (Scop.) & + & + & + & + & \\
\hline Lasioglossum (Evylaeus) convexiusculum (Schck.) & + & & & & \\
\hline Lasioglossum (Evylaeus) interruptum (Pz.) & + & & & + & \\
\hline Lasioglossum (Evylaeus) lineare (Schck.) & + & & & + & \\
\hline Lasioglossum (Evylaeus) lucidulum (Schck.) & + & & & & \\
\hline Lasioglossum (Evylaeus) marginatum (Br.) & + & & & + & \\
\hline Lasioglossum (Evylaeus) minutissimum (Schck.) & + & & & & \\
\hline Lasioglossum (Evylaeus) nigripes (Lep.) & + & & & + & \\
\hline Lasioglossum (Evylaeus) nitidiusculum (K.) & + & & & + & \\
\hline Lasioglossum (Evylaeus) pauxillum (Schck.) & + & + & & + & \\
\hline Lasioglossum (Evylaeus) politum (Schck.) & + & & & + & \\
\hline Lasioglossum (Evylaeus) punctatissimum (Schck.) & + & & & & \\
\hline
\end{tabular}




\begin{tabular}{|c|c|c|c|c|c|}
\hline Lasioglossum (Evylaeus) quadrinotatulum (Schck.) & + & & & & \\
\hline Lasioglossum (Evylaeus) semilucens (Alfk.) & + & & & & \\
\hline Lasioglossum (Evylaeus) sexstrigatum (Schck.) & + & & & + & \\
\hline Sphecodes albilabris $(\mathrm{K})$. & + & & & & \\
\hline Sphecodes cristatus Hag. & + & & & & \\
\hline Sphecodes ephippius (L.) & + & & & & \\
\hline Sphecodes ferruginatus Hag. & + & & & & \\
\hline Sphecodes gibbus (L.) & + & & & & \\
\hline Sphecodes longulus Hag. & + & & & & \\
\hline Sphecodes miniatus Hag. & + & & & & \\
\hline Sphecodes monilicornis $(\mathrm{K})$. & + & & & + & \\
\hline Sphecodes pellucidus $\mathrm{Sm}$. & + & & & & \\
\hline Sphecodes pseudofasciatus $\mathrm{Bl}$ & + & & & & \\
\hline Sphecodes puncticeps Ths. & + & + & & & \\
\hline Sphecodes rufiventris (Pz.) & + & & & & \\
\hline Nomioides minutissimus (Rossi) & + & & & & \\
\hline Nomioides variegatus (Oliv.) & + & & & & \\
\hline Rophites hartmanni Fr. & & & & + & \\
\hline Melittidae & & & & & \\
\hline Melitta tricincta $\mathrm{K}$. & & + & & & \\
\hline Macropis fulvipes (F.) & & + & & & \\
\hline Macropis labiata (F.) & & + & & & \\
\hline Dasypoda hirtipes (Fabr.) & + & & & & \\
\hline Megachilidae & & & & & \\
\hline Lithurgus chrysurus Fonsc. & + & & & + & \\
\hline Anthidium manicatum (L.) & & + & & & \\
\hline Anthidium punctatum Latr. & + & & & & \\
\hline Anthidium strigatum (Pz.) & + & & & & \\
\hline Stelis signata (Latr.) & + & & & & 8 \\
\hline Dioxys tridentata (Nyl.) & + & & & & 7 \\
\hline Chelostoma florisomne (L.) & & & + & & \\
\hline Heriades crenulatus Nyl. & + & & & & \\
\hline Heriades truncorum (L.) & + & + & + & & \\
\hline Hoplitis leucomelaena $(\mathrm{K})$. & + & & & & \\
\hline Hoplitis manicata (Morice) & + & & & & \\
\hline Hoplitis rufohirta (Latr.) & + & & & & \\
\hline Anthocopa andrenoides (Spin.) & + & & & & \\
\hline Anthocopa bidentata (Mor.) & + & & & & \\
\hline Osmia bicolor (Schrk.) & & & + & & \\
\hline Osmia coerulescens (L.) & + & & + & + & \\
\hline Osmia cornuta (Latr.) & - & & + & & \\
\hline Osmia rufa (L.) & & & + & & \\
\hline Osmia tunensis aurulenta (Pz.) & + & & & & \\
\hline Metallinella brevicornis (Fabr.) & + & & & & \\
\hline Megachile apicalis Spin. & + & & & & \\
\hline Megachile argentata (F.) & + & & & & \\
\hline Megachile centuncularis (L.) & + & + & $t$ & & \\
\hline Megachile circumcincta (K.) & + & & & & \\
\hline Megachile lagopoda (L.) & + & & & & \\
\hline Megachile maritima $(\mathrm{K})$. & + & & & & \\
\hline
\end{tabular}




\section{6. táblázat: folytatás}

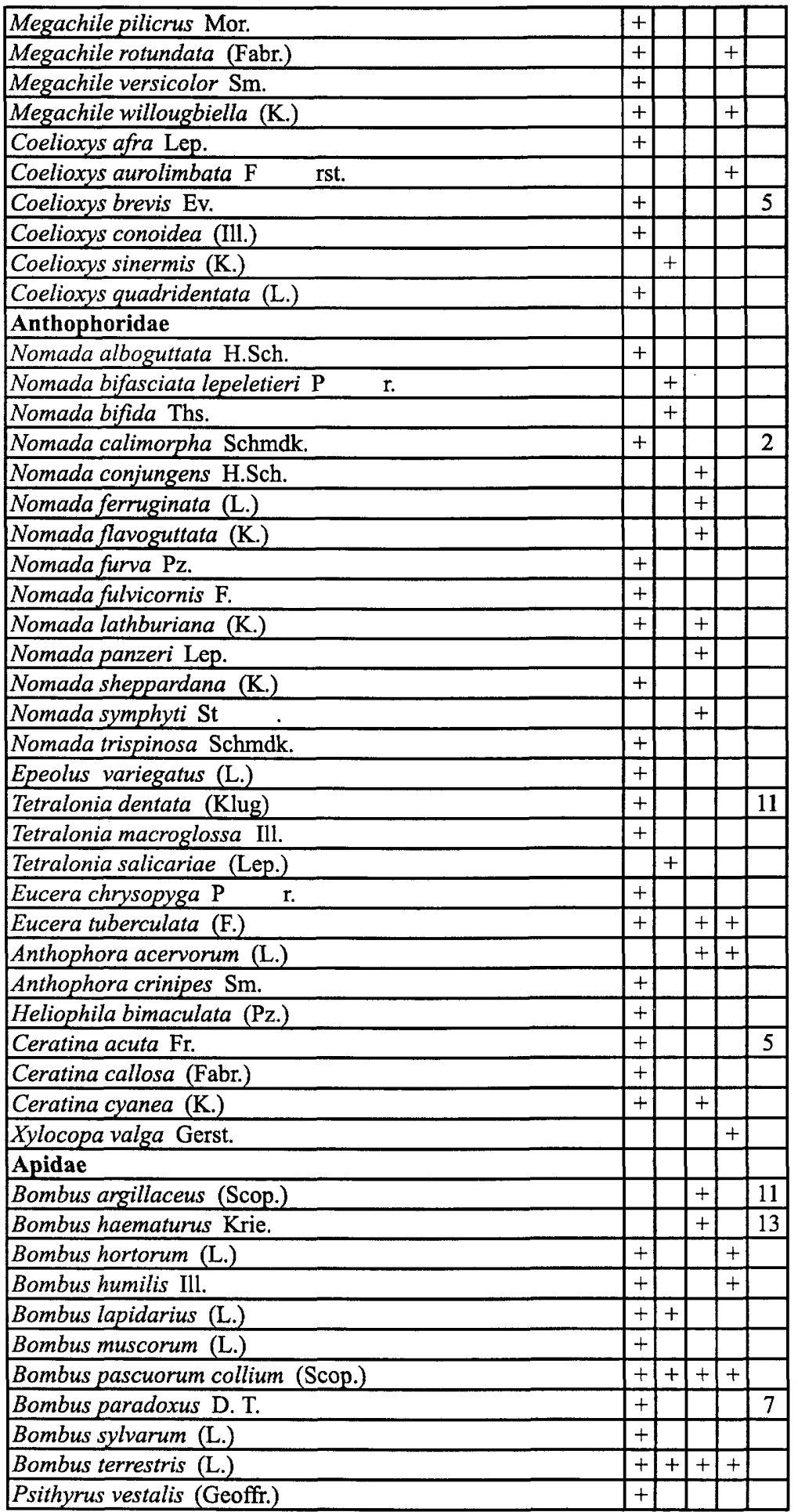




\section{Aculeata fauna of the Látrányi Puszta Nature Conservation Area (Hymenoptera: Aculeata)}

\section{ZSOLT JÓZAN}

In the vicinity of Látrányi Puszta Nature Conservation Area, the author has visited this sandy grassland almost annually since the 1970's. He carried out a faunistical research work covering the whole protected area in 1999 and in 2001 . As a result of the collected sampling, the occurrence of 403 species of the six surveyed taxa has been recorded.

Considering the size of the area, this amount of reported species is rather significant, especially, if it is compared to other surveyed areas. The distribution of species by families and subfamilies showed a great diversity in Sphecinae and Larrinae, while among Andrenidae and Halictidae species, proved to be rich in species. The distribution of recorded species was examined according to their spreading and eco-faunistical character.

Distribution of taxa and eco-faunistical character have been recorded in tables. Due to their faunistical value, it is worth mentioning Parnopes grandior, Sphex rufocinctus and Bombus argicellus, that are on the list of protected species. The faunistical values of the protected area are represented by those species which were distinctively marked in the species inventory by the number of their South-Transdanubian collecting sites. The number of these species is 63 . Among them the most typical ones are, naturally, the psammophilous species. The habitat types of the researched area are classified in four groups, each of them were thoroughly analysed. From faunistical point of view, the majority of the most valuable species were found on sandy grasslands. In addition to these areas, wetter habitats as well as arboreal areas also play an important role in sustaining species.

Considering plants, Euphorbia and Umbelliferae species proved to be the most important source of food.

A detailed description of the individual sampling places was provided and a recommendation was drafted as well, aiming to enhance environmental protection of the area. The area definitely deserves protection with regard to its Aculeata fauna. 